This manuscript is a pre-print, as it has not been published in a peerreviewed journal. Our paper has previously been submitted to Journal of Geophysical Research - Oceans and subsequently to Ocean Science, where an older version of the manuscript (initial submission, before incorporating the reviewers' comments) is also available as pre-print (https://doi.org/10.5194/os-2017-98). 


\title{
Volume transports and temperature distributions in the main Arctic Gateways: A comparative study between an ocean reanalysis and mooring-derived data
}

Marianne Pietschnig ${ }^{1,2}$, Michael Mayer ${ }^{1,2}$, Takamasa Tsubouchi ${ }^{3}$, Andrea Storto ${ }^{4}$, Sebastian Stichelberger ${ }^{1}$, Leopold Haimberger ${ }^{1,2}$

${ }^{1}$ Department of Meteorology and Geophysics, University of Vienna, Vienna, Austria

${ }^{2}$ Austrian Polar Research Institute, Vienna, Austria

${ }^{3}$ Physical Oceanography of the Polar Seas group, Alfred Wegener Institute for Polar and Marine Research, Bremerhaven, Germany

${ }^{4}$ Ocean Modeling and Data Assimilation Division, Centro Euro-Mediterraneo sui Cambiamenti Climatici, Bologna, Italy

Correspondence to: Marianne Pietschnig (mp586@exeter.ac.uk), Current affiliation: Department of Mathematics, University of Exeter, Exeter, UK

\begin{abstract}
Oceanic transports through the Arctic gateways represent an integral part of the polar climate system, but comprehensive insitu-based estimates of this quantity have been lacking in the past. New observation-based estimates of oceanic volume, temperature and freshwater transports have recently become available. Those estimates have been derived from moored observations in the four major gateways by applying mass and salinity constraints. We seize this opportunity to compare a recent ocean reanalysis with those observation-based estimates. First, time series of integrated volume transports through each strait are considered, along with the net heat transport into the Arctic Ocean. Good agreement is found for Davis Strait volume transports, but considerable disagreement of up to $1.1 \mathrm{~Sv}$ in Fram Strait and the Barents Sea Opening. The annual mean net volume export through the gateways is $-0.03 \pm 0.23 \mathrm{~Sv}$ in the reanalysis, weaker than the $-0.15 \pm 0.06 \mathrm{~Sv}$ derived from the observation-based estimate (uncertainties represent the monthly standard deviation). The net ocean heat transport to the Arctic Ocean is similar in the two datasets (observation-based: $153 \pm 44 \mathrm{TW}$, reanalysis: $145 \pm 35 \mathrm{TW}$ ). Discrepancies in the integrated transports are further investigated by studying cross-sections of velocity and potential temperature. These reveal good qualitative agreement in all straits, but considerable differences in the strength of major features like the East Greenland Current and the West Spitzbergen Current. Examination of the instrumental coverage reveals that areas of discrepancy are often co-located with poorly observed regions. In conclusion, both types of data sets have their merits and are recommended to be used complementarily for climate studies in this data-sparse region. The results presented in this study can contribute to the planning of future observational efforts and to the development of ocean reanalysis products.
\end{abstract}




\section{Introduction}

Research in the Arctic region is motivated by observed changes in the Arctic climate, including a downward trend in sea ice extent and thickness over the past few decades (Comiso et al., 2008; Kwok and Rothrock, 2009; Parkinson and Comiso, 2013; Stroeve et al., 2012) and above-global-average surface air temperature increase (Serreze et al., 2009). These changes affect the mean and the seasonal cycle of the coupled Arctic energy budget, including atmosphere, ocean, and sea ice (Mayer et al., 2016).

Ocean heat transport is a relevant part of the Arctic energy budget, contributing approximately $10 \%$ to the total energy transport into the polar cap. The oceanic transport is roughly $150 \mathrm{TW}$ (Tab. 1), compared to $1290 \mathrm{TW}$ transported by the atmosphere (derived from $84 \mathrm{~W} / \mathrm{m}^{2}$ multiplied by the ocean surface area of the Arctic domain $15.4 \times 10^{6} \mathrm{~km}^{2}$, Serreze et al., 2007). Ocean heat transport also exhibits considerable variability on inter-annual timescales modulating the Arctic energy budget (Årthun et al., 2012; Mayer et al., 2016). However, there is no consensus among climate models on the contribution of oceanic transports to Arctic warming (Burgard and Notz, 2017). Reliable observation-based estimates of this important physical quantity are therefore needed to better understand involved processes. Ocean heat transport is difficult to observe directly and thus ocean and sea-ice retrospective analyses (or "reanalyses") represent a valuable data source for this purpose.

Reanalyses provide the four-dimensional state of the ocean and sea-ice constrained by available observations over multidecadal time periods, albeit with large uncertainties in data-sparse regions like the Arctic. The development and continuous improvement of reanalysis products facilitates the investigation of mechanisms involved in the aforementioned changes, especially in remote regions with limited observational coverage (Balmaseda et al., 2013). A reanalysis consistently uses the same modeling and data assimilation framework throughout the covered period and ingests quality controlled observational datasets. The ocean reanalysis chosen for our study is the Centro Euro-Mediterraneo sui Cambiamenti Climatici (CMCC) Global Ocean Reanalysis (C-GLORS) version 7. Assessing the reliability of reanalyses is crucial for qualifying these datasets for long-term studies. An important method for validating ocean reanalysis products is to compare the output fields or derived quantities with observation-based estimates (Masina et al., 2011). Ideally, those observations are "independent", meaning that they are not assimilated in the reanalysis. In-situ measurements of currents, which are usually not assimilated, are therefore well-suited for validation purposes (Masina et al., 2011).

Over many years, the four major Arctic gateways which connect the Arctic Ocean to the Atlantic and Pacific Ocean have been monitored by several research groups in the world (Dickson et al., 2008; Haine et al., 2015). Tsubouchi et al. (2018) quantify, for the first time, the seasonal cycle of ocean and sea ice net heat and fresh water fluxes around the Arctic ocean boundary based on observational data from the moored array using a box inverse model. These moorings are not included in the UK Met Office Hadley Centre EN4 dataset (Good et al., 2013), which contains the temperature and salinity profiles assimilated in C- 
GLORS (Storto, 2016; Storto and Masina, 2016b). Therefore, this observation-based dataset (OBS) can be considered largely independent of the C-GLORS reanalysis, except in the Barents Sea Opening (see Sect. 2.2 for further discussion).

In previous studies comparing reanalyses to observations in the Arctic Gateways such as Ilıcak et al. (2016) and Zuo et al. (2011), the observation-based estimates are compiled from various authors who calculate transports for individual straits. Those estimates are therefore not necessarily consistent with each other and might not be suitable for total Arctic mass and energy budget evaluations. For example, volume fluxes are sensitive to the period under consideration due to the large interannual variability in some of the straits. Additionally, quality control of hydrographic observations and methods to derive volume transports from those observations can differ among authors. The observation-based dataset used here is unique because of its homogeneity in the processing of the observational datasets to provide consistent transport estimates across the major Arctic gateways.

Tsubouchi et al. (2018) focus on the period from September 2005 to August 2006. We examine C-GLORS and OBS transports and state quantities for this one-year period. The region for comparing C-GLORS with OBS is defined by the locations of moorings in the Arctic Gateways. In the present study, the Arctic Ocean is therefore defined to be north of Davis Strait, similar to Haine et al. (2015), and not north of the Canadian Arctic Archipelago (CAA) as in Serreze et al. (2007). Figure 1 shows a map of those gateways, as well as the volume transports for the main currents through those straits as estimated in this study.

Two different methods to compare C-GLORS with OBS are employed: First, we investigate time series of monthly volume transports integrated across the individual straits, and of the net volume and heat transports. Second, cross-sections of velocity and potential temperature are plotted for both datasets. Discrepancies in the spatial distribution of velocities can then be linked to the comparison of the integrated volume transports. Comparison of the distribution of potential temperatures across the straits can give further insight into the discrepancies between the two datasets. Previous studies comparing cross-sections obtained from models or reanalyses against observational data in the Arctic Gateways include Kawasaki and Hasumi (2016), Zuo et al. (2011) and Fieg et al. (2010). We believe that it is valuable to extend previous efforts and investigate cross-sections and integrated transports through the four major Arctic gateways in one comprehensive study. We now have the opportunity to do so since an internally consistent mooring-derived dataset has become available.

The paper is structured as follows: We provide a brief overview of the observation-based data and the reanalysis in Sect. 2. The methods are introduced in Sect. 3. Results of our comparison of time series and cross-sections are presented in Sect. 4. In the last section, we summarize the results, draw conclusions, and give an outlook for further research. 


\section{Data}

\subsection{Observation-based data (OBS)}

Integrating the individual mooring arrays across the Arctic boundary (Davis, Fram, and Bering Strait and the Barents Sea Opening), Tsubouchi et al. (2018) quantify the seasonality of oceanic volume, heat and freshwater transports under mass and salinity constraints. The study focuses on the period from September 2005 to August 2006, which is the first year for which comprehensive mooring observations of the Arctic boundary are available. The complete observation of all major gateways commenced in October 2004, but several instruments in the western part of deep Fram Strait (designed to capture the variability of the East Greenland Current) could not be fully recovered in that year.

The main data source are 138 moored instruments spread across the Arctic gateways. The instruments include temperatureand salinity-measuring devices (SeaBird Electronics MicroCATs, SBE), acoustic Doppler current profilers (ADCP) taking velocity profiles, and single-point current meters (Aanderaa RCMs) which measure temperature, velocity and in some cases also salinity. In the Barents Sea Opening (BSO), where instrumental coverage is limited, the moorings are supplemented by hydrographic measurements from nine cruises conducted during the period September 2005 to August 2006. The locations and types of moored instruments in the individual straits are shown in Fig. 3 - 7. Detailed descriptions of the moorings in each strait can be found in Curry et al. (2014) for Davis Strait, Beszczynska-Möller et al. (2012) for Fram Strait, Ingvaldsen et al. (2004) for the BSO and in Woodgate et al. (2015) for Bering Strait. Sea ice transport is estimated using Pan-Arctic Ice Ocean Modeling and Assimilation System output (PIOMAS, Zhang and Rothrock, 2003).

Model output from the Nucleus for European Modelling of the Ocean (NEMO) with 1/12 ${ }^{\circ}$ resolution is used in regions where moored observations are lacking. This includes the upper ocean above the shallowest instruments (above $50 \mathrm{~m}$ in Fram and Bering Strait and above $100 \mathrm{~m}$ in Davis Strait) and in the shelf regions: Belgica Bank in Fram Strait and north of Bear Island in the BSO (Tsubouchi et al., 2018). A comprehensive assessment of the NEMO ocean model at $1 / 12^{\circ}$ resolution has, to our knowledge, not been conducted for all Arctic Gateways so far. However, good performance of NEMO in the east Greenland shelf region has been reported by Bacon et al. (2014). According to their study, the NEMO $\left(1 / 12^{\circ}\right.$ resolution) coupled to the Louvain-la-Neuve sea ice model (LIM2, Fichefet and Maqueda, 1997) reliably represents the East Greenland Coastal Current (EGCC). The influence of including NEMO model output on the volume transports is dominated by the shelf regions rather than the upper $50 \mathrm{~m}$ in Fram Strait. This is due to the fact that the moored observations do not capture the anti-cyclonic circulation over Belgica Bank (more than $1 \mathrm{~Sv}$ ) in Fram Strait nor polar water outflow from the Arctic Ocean in the western side of Davis Strait (up to $0.5 \mathrm{~Sv}$, personal communication with T. Tsubouchi). 
The observational data are vertically and horizontally interpolated to fill a regular grid with $3 \mathrm{~km}$ horizontal spacing (given by the resolution of NEMO $1 / 12^{\circ}$ data) and 1 dbar vertical spacing. The actual interpolation scheme differs slightly from gateway to gateway, depending on the instrument types and data coverage. In Davis Strait for example, velocities are extrapolated from the deepest measurements at $500 \mathrm{~m}$ to zero velocity at the ocean bottom. In the BSO, velocity measurements are sparse, so geostrophic velocities are derived from salinity and temperature data. Then, mass and salinity conserved monthly fields of velocity are derived using a box-inverse model for the consecutive twelve months (see Tsubouchi et al., 2018 for the full description of data treatment in the individual straits). The main outcomes of the study such as twelve monthly oceanic transport time series and temperature, salinity and velocity fields, are available through the data publisher PANGAEA (Tsubouchi et al., 2017). It is worth mentioning that the effective spatial resolution of the output fields is limited by the moored instrument positions. They are typically located 100-1000 m apart in the vertical and 20-50 km apart in horizontal direction.

\subsection{C-GLORSv7}

The CMCC Global Ocean Physical Reanalysis System (C-GLORSv7) is an ocean reanalysis at eddy-permitting resolution (approximately $1 / 4^{\circ}$ ) with 75 vertical depth levels. C-GLORSv7 covers the period from 1993 to 2016 and is being updated in delayed time mode, with a lag of approximately one year. The ocean model component of C-GLORSv7 is NEMO (Madec, 2008) version 3.6, which is implemented on the tripolar ORCA025 grid with Arakawa C-grid staggering and partial steps (Bernard et al., 2006). The resolution of the model allows eddies to be resolved approximately between $50^{\circ} \mathrm{S}$ and $50^{\circ} \mathrm{N}$ (Penduff et al., 2010). The resolution is higher in the Arctic region (about $9 \mathrm{~km}$ ) compared to low latitudes, but at the same time the Rossby radius is smaller here (about $10 \mathrm{~km}$ in the deep basins) so that the reanalysis is not eddy-resolving in our study region (Bacon et al., 2015). The sea-ice model LIM2 is coupled to NEMO at a 2-hourly frequency. LIM2 is a three-layer (two of sea ice and one of snow) thermodynamic-dynamic sea-ice model that implements elasto-visco-plastic rheology (Bouillon et al., 2009). The model is forced by the European Centre for Medium Range Weather Forecasts (ECMWF) ERA-Interim reanalysis (Dee et al., 2011) using the CORE bulk formulas (Large and Yeager, 2009).

C-GLORSv7 assimilates all hydrographic profiles from XBTs (expendable bathythermographs), CTDs (ConductivityTemperature-Depth), Argo floats, moorings and sea-mammals extracted from the UK Met Office EN4 dataset (Good et al., 2013) and along-track altimetry data provided by AVISO (Archiving, Validation and Interpretation of Satellite Oceanographic data, Le Traon and Ogor, 1998) through a three-dimensional variational (3DVAR) data assimilation system with first guess at appropriate time (FGAT). The 3DVAR/FGAT assimilation scheme corrects the model fields every seven days. Backgrounderror covariances are derived from monthly anomalies with respect to long-term averages from a free simulation (Storto et al., 2014) and have been re-tuned to match output assimilation statistics as the ones proposed by Desroziers et al. (2005). Additionally, C-GLORSv7 implements a surface nudging scheme to assimilate sea surface temperature daily analyses from Reynolds et al. (2007), sea-ice concentration data from the Met.no OSI-SAF reprocessed dataset and, in the Arctic Ocean, sea- 
ice thickness reconstructions from PIOMAS. A large-scale bias correction scheme is also implemented to reduce model biases and drifts (Storto et al., 2016). The data assimilation of C-GLORSv7 includes an improved scheme for the quality control of observations (Storto, 2016).

None of the moorings which are used in preparation of OBS were assimilated in the reanalysis, but CTD data from several cruises were assimilated in the Barents Sea Opening during seven months throughout the study period. In this case, OBS is only independent of the reanalysis concerning velocities, but not temperature or salinity, since the sparse moored observations are supplemented by vessel based CTD data in this strait. In Fram Strait and Davis Strait, CTD data are assimilated for one month each, namely November 2005 for Fram Strait and July 2006 for Davis Strait. No temperature or salinity data are assimilated in Bering Strait, so that OBS is largely independent of the reanalysis in those three straits.

The latest release of C-GLORS (v7) is now part of the Copernicus Marine Environment Monitoring Service (CMEMS, http://marine.copernicus.eu) and is freely released through the website http://c-glors.cmcc.it. We conduct our comparisons between OBS and the reanalysis for C-GLORSv7 without (v7 control) and with (v7) data-assimilation and surface nudging to investigate the influence of the sparse observations on the reanalysis at such high latitudes. We are interested in the performance of C-GLORSv7 in the Arctic Ocean, as this reanalysis is one of the state-of-the-art ocean reanalysis products that are currently available. Previous releases of C-GLORS have been validated extensively on a global scale (Storto et al., 2016; Storto and Masina, 2016a). For example, Storto and Masina (2016a) estimated that temperature errors of C-GLORS (v5, the predecessor of $\mathrm{v} 7 \mathrm{used}$ here) lie below $1{ }^{\circ} \mathrm{C}$ in the upper $10 \mathrm{~m}$ of the Arctic Ocean. C-GLORS has also been used for a variety of climate applications, including studies investigating North Atlantic Ocean climate variability (Yang et al., 2016) and the energy budget of the Arctic cap (Mayer et al., 2016). Additionally, biogeochemical, fishery and larval disposal models are coupled off-line to C-GLORS. A recent ocean reanalysis intercomparison study conducted by Uotila et al. (2018) for the polar regions for the period 1993 to 2010 shows that the net oceanic heat transport into the Arctic in C-GLORSv5 is close to the multi-model mean. Additionally, the representation of the mean state of ocean heat and salt contents in the layer from $0 \mathrm{~m}$ to $1500 \mathrm{~m}$ depth in C-GLORSv5 is of comparable quality to the other reanalyses (Uotila et al., 2018).

\section{Materials and Methods}

Following Bacon et al. (2015), the vertically integrated mass balance of the liquid Arctic Ocean with volume V and lateral boundary A (represented by the oceanic straits) can be expressed through

$\iiint_{V} \frac{\partial \rho_{w}}{\partial t} d V=\iint_{A} \rho_{w} v_{\perp} d s d z+F_{m}{ }^{s}$ 
Here, $\rho_{\mathrm{w}}$ is the density of sea water (set to $1026 \mathrm{~kg} / \mathrm{m}^{3}$ ), $\mathrm{v}_{\perp}$ is the velocity component normal to the lateral boundary A (positive northward and eastward in the Barents Sea Opening). Adopting a slightly altered notation from Bacon et al. (2015), we denote transports or fluxes with F, and use the subscripts ' $\mathrm{V}$ ' for volume and ' $\mathrm{m}$ ' for mass. Integration is with respect to ds and dz, which represent horizontal and vertical coordinates along A, respectively. This equation expresses the fact that under stationary conditions (when the left-hand side equals zero), horizontal export of mass balances the surface freshwater flux $\left(\mathrm{F}_{\mathrm{m}}^{\mathrm{S}}\right.$, the superscript " $\mathrm{S}$ " stands for surface). $\mathrm{F}_{\mathrm{m}} \mathrm{S}$ is the difference between the sum of precipitation $\mathrm{P}$, river runoff $\mathrm{R}$ and ice melt $\mathrm{M}$ (all are positive downward) and evaporation $\mathrm{E}$ (positive upward). $\mathrm{F}_{\mathrm{m}} \mathrm{S}$ is defined positive downward.

First, monthly fields of meridional and zonal volume transports $\left(\mathrm{F}_{\mathrm{V}}\right)$ and 'temperature transports $\left(\mathrm{F}_{\theta}\right)$ ' are calculated from reanalysis fields for each point and vertical level on the model-native (tripolar) grid. The transports for each grid cell are denoted with an asterisk $\left(\mathrm{F}_{\mathrm{V}} *\right.$ and $\left.\mathrm{F}_{\theta}{ }^{*}\right)$, so they are distinguishable from the integrated transports through the straits. Computation of $\mathrm{F}_{\mathrm{V}} *$ is straightforward, using velocity fields and vertical and horizontal geometry of the staggered reanalysis grid. $\mathrm{F}_{\theta} *$ is calculated using

$F_{\theta}^{*}=\rho_{w} c_{p}\left(\bar{\theta}-\theta_{\text {ref }}\right) \cdot \overline{v_{2}} \cdot A_{c}$

where $\mathrm{c}_{\mathrm{p}}=3990 \mathrm{~J} / \mathrm{kgK}$.

Schauer and Beszczynska-Möller (2009) explained that whenever the net volume transport into a study area is not equal to zero, the choice of reference temperature will affect the temperature transport through this section. For this reason, we do not present results for $\mathrm{F}_{\theta} *$, nor for the integrated $\mathrm{F}_{\theta}$ through individual straits, but we use $\mathrm{F}_{\theta} *$ in the computation of the net heat transport for the closed Arctic Ocean boundary where the volume transport is almost balanced. Additionally, we use $\theta_{\text {ref }}=0$ ${ }^{\circ} \mathrm{C}$, which minimizes the influence of the small net volume export from the Arctic region onto the net heat transport (see Sect. 4.1). Potential temperature is denoted by $\theta$ and the component of the horizontal velocity (zonal on the u-grid and meridional on the v-grid) by $\mathrm{v}_{2}$. The overbar indicates monthly averages, and $\mathrm{A}_{\mathrm{c}}$ stands for the vertical area of the respective grid cell. The temporal resolution of C-GLORS output is daily, but due to the monthly resolution in the observation-based dataset, $\mathrm{F}_{\theta} *$ is computed as described above.

Second, the C-GLORS grid points ('transport points'), which are closest to the grid of the mooring-derived data, are identified in each strait (see Fig. S1 - S4 in the supporting information). Vertically integrated $\mathrm{F}_{\mathrm{V}} *$ and $\mathrm{F}_{\theta} *$ in each of those points are summed up over the respective strait, using meridional transports and zonal transports according to the location of the points on the staggered grid. We carefully select the points on the reanalysis grid so that we obtain a closed line integral for the Arctic Ocean boundary without counting meridional or zonal transports twice. In the example of Fram Strait, this means choosing the points on the reanalysis grid (tri-polar) which follow $79^{\circ} \mathrm{N}$ as closely as possible. The vertically integrated transport in 
each point corresponds to the transport through the water column with the width of one grid cell centered on the respective point. The limits of integration are the ocean bottom and the sea surface. Thus, we are neglecting the contribution of transports through the steric sea surface height (Storto et al., 2015). We obtain the monthly transport through each strait by summing up the values at all 'transport points'. Finally, the time series of temperature and volume transports can be plotted for our oneyear study period.

Third - in preparation for the cross-section plots - the C-GLORS velocity vector in each transport point is computed by interpolating meridional velocities (given on the $\mathrm{v}$-grid) onto the $\mathrm{u}$-grid, and zonal velocities (given on the u-grid) onto the $\mathrm{v}$ grid. Meridional and zonal directions are derived from the grid geometry. The velocity vector is then projected onto the unit vector normal to the observation-based grid, thus obtaining the C-GLORS velocity in the direction of the observation-based flow. In order to obtain the same spatial resolution for both datasets for plotting cross-sections, the observation-based temperature and velocity fields are horizontally averaged over the appropriate grid points to match the higher horizontal resolution of the reanalysis for the cross-section plots. Similarly, C-GLORS fields are vertically interpolated to meet the higher vertical resolution of the observation-based grid. Finally, cross-sections showing the distribution of potential temperature and velocity across each strait are prepared.

We note that the error introduced by using monthly mean $\theta$ and velocity fields for calculating monthly temperature transports (see Eq. 2) instead of using the daily fields is small. Following for example Peixoto and Oort (1992), the product of Reynolds decomposed temperature and velocity fields gives $\overline{v_{2} \cdot \theta}=\overline{v_{2}} \cdot \bar{\theta}+\overline{v_{2}{ }^{\prime} \cdot \theta^{\prime}}$. The overbar denotes monthly means, while the primed quantities represent daily fields. This expression states that the monthly mean temperature transport $\overline{v_{2} \cdot \theta}$ (obtained by multiplying daily fields and then averaging over each month) can be split up into the 'stationary circulation' (first term on the righthand side) and the contribution from 'transient eddies', i.e. sub-monthly scale fluctuations. Based on the C-GLORS data, we find that the correlation of daily $\theta$ and v fields contributes less than $1 \%$ to the net heat transport into the Arctic Ocean (see Fig. S5 in the supporting information). Horizontal heat transports at those high latitudes therefore seem to be dominated by the stationary circulation (Valdivieso et al., 2014).

The argument above for neglecting the contribution of turbulences $\left(\overline{v_{2}^{\prime} \cdot \theta^{\prime}}\right)$ to the net heat transport has no implication for the importance of mesoscale eddies (Eddy kinetic energy $=1 / 2 \cdot\left(\overline{u^{\prime} \cdot u^{\prime}}+\overline{v^{\prime} \cdot v^{\prime}}\right)$, e.g. Hattermann et al., 2016) for the strength of the circulation in the gateways. Several authors discuss the need for reanalyses and observations with high spatial resolution in order to capture the entire transport through the Arctic gateways due to the small Rossby radius of deformation at high latitudes (Beszczynska-Möller et al., 2011; Drange et al., 2005; Hattermann et al., 2016). 


\section{Results}

The comparison between C-GLORSv7 and the observation-based time series (Fig. 2, Tab. 1) reveals that there is considerable disagreement in the transports through the individual straits. The average volume transport is closest to the observation-based estimate in Davis Strait (- 2.1 $\pm 0.7 \mathrm{~Sv}$ from the observation-based data, - $2.3 \pm 0.4 \mathrm{~Sv}$ from C-GLORSv7). On a month-tomonth basis the timeseries from the reanalysis closely follow the observation-based timeseries in Bering Strait and the BSO, which is also reflected in high correlation coefficients between the two datasets for Bering Strait (0.97) and the BSO (0.76). All transport estimates are presented with the monthly standard deviation $(1 \sigma)$, which mainly represents the temporal variability during the one-year study period, rather than being a measure for the uncertainty of our estimates.

\subsection{Net transports}

The net (sum over all straits) volume transport out of the Arctic region is - $0.03 \pm 0.23 \mathrm{~Sv}$ from C-GLORSv7 and - $0.15 \pm 0.06$ Sv based on OBS (Tab. 1 and Fig. 2). Even though the absolute difference is small, the relative discrepancy is quite substantial and the temporal variability of C-GLORSv7 is a factor of four larger than in OBS. The volume export is due to a positive timemean $\mathrm{F}_{\mathrm{m}} \mathrm{s}$. For computation of the observation-based data, the initial surface freshwater flux is set to $0.18 \mathrm{~Sv}$, based on climatological 'P minus E' and R values compiled from a few different sources (Tsubouchi et al., 2012). We would like to point out that the observation-based volume transport estimate of $-0.15 \pm 0.06 \mathrm{~Sv}$ together with the volume transport by sea ice (- $0.07 \mathrm{~Sv}$, derived from $-2080 \mathrm{~km}^{3} / \mathrm{yr}$, Haine et al., 2015, using $1 \mathrm{~Sv}=31,536 \mathrm{~km}^{3} / \mathrm{yr}$ ) nicely balances the $0.20 \pm 0.08 \mathrm{~Sv}$ surface freshwater flux obtained from the inverse-model calculations, as discussed by Tsubouchi et al. (2018). This is also in excellent agreement with the updated surface freshwater flux estimate of $0.203 \pm 0.016 \mathrm{~Sv}$ (or $6400 \mathrm{~km} 3 / \mathrm{yr}$, Carmack et al., 2016). In C-GLORS, 'P minus $E$ ' is derived from a combination of ERA-Interim short term forecasts (P) and bulk formulae (E), and a climatological $\mathrm{R}$ is used as well as a damping term to satisfy global conservation requirements (Storto and Masina, 2016b).

The net heat transport integrated over the study area is slightly larger in OBS ( $153 \pm 44 \mathrm{TW})$ than in C-GLORSv7 (145 \pm 35 TW, Tab. 1) but the estimates match within the temporal variability. Technically, these integrated transports are still dependent on the reference temperature because of the (small) net volume flux discussed above. However, based on the product of the average temperature of the Arctic Ocean boundary $\left(1.1 \pm 0.2{ }^{\circ} \mathrm{C}\right.$ from both datasets) with the respective net volume transports and appropriate constants, we find that the contribution of the net mass flux to the net heat transport is negligible (- $0.60 \pm 0.24$ TW for the observation-based data, $-0.07 \pm 1.06 \mathrm{TW}$ for C-GLORSv7) due to the appropriate choice of $\theta_{\text {ref. }}$ It is difficult to compare our estimates of the net heat transport to previously published results, as observation-based net heat transport estimates are sparse. In the following paragraph we would like to discuss how interannual variability of volume transports and temperatures at the gateways might have affected the net heat transport during our study period. 
As reported by Beszczynska-Möller et al. (2012), there was a warm temperature anomaly in Fram Strait from 2005 to 2007 spreading from the northward flowing West Spitzbergen Current (WSC) in the East all the way across the strait to the outflowing East Greenland Current (EGC) in the West of deep Fram Strait. These warmer inflows in the WSC might have led to an anomalously high net heat import during our study period. However, the outflowing EGC also saw warm anomalies, which would partly compensate the warmer WSC inflow. In addition, the heat transport is also affected by changes in the volume transport. While the warm anomaly was strongest in the very stable West Spitzbergen Core current, it also affected the strongly varying offshore current and the largely wind-driven EGC (de Steur et al., 2014). Bering Strait saw anomalously low volume imports during 2005 while annual mean temperatures were slightly positive and remained fairly close to the long-term mean (Woodgate et al., 2012), which might indicate a slightly negative contribution to the net heat import. Inferring from Curry et al. (2014, Fig. 4), due to above-average (2004-2010) volume export in the Baffin Island Current during our study period but representative, negative temperatures in the same region, we might expect an anomalously high contribution to the net heat import from Davis Strait. Volume transports through the BSO were increasing during the period 1997 - 2006, with particularly pronounced increases during 2005 - 2006 (Skagseth et al., 2008). Together with above-average temperatures in the section (Skagseth et al., 2008), the flow through the BSO might have contributed positively to the net heat import during our study period. Taking all the above into consideration and looking at the net heat transport anomalies for the period 2000 2013 through $70^{\circ} \mathrm{N}$ from the reanalysis (see supplementary material, Fig. S7), we tentatively conclude that the net oceanic heat transport was above average during our study period. This is further supported by Zuo et al. (2011), who estimated a multi-annual (1987 - 2004) averaged net ocean heat transport of 130.5 TW into the Arctic based on the University of Reading reanalysis product UR025.1 with $1 / 4^{\circ}$ resolution and 46 vertical levels.

\subsection{Davis Strait}

The volume export through Davis Strait derived from the reanalysis (- $2.3 \pm 0.4 \mathrm{~Sv})$ is close to the observation-based estimate (- $2.1 \pm 0.7$ Sv, Tab. 1). Zuo et al. (2011) estimated a multi-annual averaged $F_{V}$ through Davis, Fury and Hecla Straits of - 2.4 $\pm 0.4 \mathrm{~Sv}$. The estimates derived from both C-GLORSv7 and OBS seem realistic compared to this literature value. A more recent model intercomparison study presented a multi-model annual mean transport of - 1.75 Sv through Davis Strait for the period 1948 - 2007 (Ilicak et al., 2016). Most of the models from that study have a lower resolution than C-GLORSv7, with exception of one model (MOM0.25) with the same resolution as C-GLORS $\left(1 / 4^{\circ}\right)$. None of the considered models is eddy resolving in our study region. A $1 / 12^{\circ}$ model is, at best, eddy permitting in deeper parts of the Arctic boundary in Fram and Davis Strait (Dupont et al., 2015). The long-term mean (- $2.12 \pm 0.88 \mathrm{~Sv}, 1978$ - 2007) from such a 1/12 ${ }^{\circ}$ model is in very good agreement with our C-GLORSv7 and OBS estimates (Marzocchi et al., 2015). However, both the models and observations mentioned above are too coarse to capture small-scale eddies in Davis Strait, and thus the estimates, including the ones derived in this study for C-GLORSv7 and OBS, are unlikely to be accurate (Beszczynska-Möller et al., 2011). 
Our observation-based estimate of the volume transport through Davis Strait agree with the - $1.7 \mathrm{~Sv}$ estimate presented by Curry et al. (2014) averaged from October 2005 to September 2006 within the given uncertainty range of $0.5 \mathrm{~Sv}$. The difference between the two values may be related to the method by which volume transports are quantified. Curry et al. (2014) employed a different interpolation method to obtain gridded velocity fields in Davis Strait. While Curry et al. (2014) used optimal interpolation, Tsubouchi et al. (2017) used linear interpolation. In addition, Curry et al. (2014) included data from seagliders which were not used by Tsubouchi et al. (2017). This increases the spatial resolution of the observations as well as providing information on the upper $100 \mathrm{~m}$, which are not captured by the moored array. The long-term (2004 - 2010) estimate presented by Curry et al. (2014) is slightly lower $(-1.6 \pm 0.5 \mathrm{~Sv})$, although this is partly due to anomalously low transports of $1.3 \mathrm{~Sv}$ during 2007.

The cross-section plots for Davis Strait from OBS (Fig. 3a, left column) show that there is a northward current in eastern Davis Strait (east of $57^{\circ} \mathrm{W}$, distance $\mathrm{d}=200 \mathrm{~km}$ in the plots), transporting $1.2 \pm 0.7 \mathrm{~Sv}$ (Fig. 1) of relatively warm water (area and time averaged temperatures of $2.4 \pm 0.5{ }^{\circ} \mathrm{C}$ ) into the Arctic Ocean. In C-GLORSv7 (Fig. 3a, middle column), there is a small northward current in this area but mostly the velocities are close to zero. The average transport is - $0.1 \pm 0.7 \mathrm{~Sv}$ (C-GLORSv7, Fig. 1), with negative transports between January and July. This is in contrast to OBS, where the currents remain northward throughout the study period. The average temperature of the current is $2.0 \pm 0.2^{\circ} \mathrm{C}$ in C-GLORSv7. According to BeszczynskaMöller et al. (2011), the flow in this region is observed to be northward. It consists of Arctic waters in the West Greenland Current above the shelf and the West Greenland Slope Current of Atlantic origin. Those waters circulate anticlockwise in Baffin Bay and join the outflowing Baffin Island Current $(\mathrm{d}=0$ to $200 \mathrm{~km})$ in the West of Davis Strait (Beszczynska-Möller et al., 2011). In this region, the volume export in OBS is greater (- $3.4 \pm 0.7 \mathrm{~Sv}$, Fig. 1) than in C-GLORSv7 (- $2.2 \pm 0.6 \mathrm{~Sv})$. Temperatures are generally lower than in the East $\left(0.6 \pm 0.3{ }^{\circ} \mathrm{C}\right.$ OBS, $1.1 \pm 0.1{ }^{\circ} \mathrm{C} \mathrm{C}$-GLORSv7), partly because temperatures are negative in the upper $200 \mathrm{~m}$ in western Davis Strait.

The agreement is better in both parts of Davis Strait for the control experiment (Fig. 3b). In eastern Davis Strait, we find an average northward flow of $0.3 \pm 0.4 \mathrm{~Sv}$ and $2.4 \pm 0.8^{\circ} \mathrm{C}$ warm waters in the control experiment. The current is predominantly northward (except for January - March), and temperatures are positive all year. The agreement is also better between the control experiment $\left(\mathrm{F}_{\mathrm{V}}=-3.1 \pm 0.5 \mathrm{~Sv}, \theta=0.5 \pm 0.2{ }^{\circ} \mathrm{C}\right)$ and $\mathrm{OBS}$ in western Davis Strait. It seems like the stronger inflow and outflow in the control experiment compared to the full C-GLORSv7 can be related to the stronger horizontal temperature gradient in the control experiment in the upper $300 \mathrm{~m}$. This implies a stronger zonal density gradient, which, assuming geostrophic balance, could explain the enhanced patterns of meridional velocities in Davis Strait.

Instrumental coverage in Davis Strait above $500 \mathrm{~m}$ is relatively high (see Fig. 3a). However, some of the instruments did not record any data during the study period or parts of it (see supporting information of Tsubouchi et al., 2018). This is true close 
to Baffin Island in the West and over the slope in Eastern Davis Strait, which are regions of major discrepancy between OBS and C-GLORSv7.

So far, the only uncertainty measure we have provided was one standard deviation from the annual mean. We would also like to include the uncertainty estimates provided in Tsubouchi et al. (2012) for Summer 2005. This 'a posteriori' uncertainty is derived from the 'a priori' uncertainty, which is based on spatial coverage and temporal variability of the measured quantity (see Tsubouchi et al., 2012 for full details of the uncertainty computation). The Davis Strait transport for Summer 2005 was estimated at - 3.1 $\pm 0.7 \mathrm{~Sv}$, where we have adopted the italic notation from Tsubouchi et al. (2018) in order to distinguish between temporal variability (normal font) and the box-inverse model derived uncertainty (italic).

To facilitate the comparability to other studies which define the boundary of the Arctic Ocean to be north of the CAA, we investigate the volume transport through Baffin Bay in C-GLORSv7 during the study period. The sum of the transports through Lancaster Sound (LS), Cardigan Strait (CS), Hell Gate (HG) and Nares Strait is - $1.9 \pm 0.4$ Sv. The contributions from the individual straits are $-0.6 \pm 0.2 \mathrm{~Sv}$ (LS), $0.25 \pm 0.08 \mathrm{~Sv}$ (CS), zero contribution from HG and the largest contribution from Nares Strait $(1.1 \pm 0.2 \mathrm{~Sv})$. The volume transport estimates are in good agreement with observation-based estimates in all straits (Lancaster Sound: - 0.53 Sv, 1998 - 2006, Peterson et al., 2012, Cardigan Strait plus Hell Gate: - 0.3 Sv, 2000 - 2002, Melling et al., 2008, Nares Strait: 1.03 Sv, 2007 - 2009, Münchow, 2016). The average temperature in the Canadian Straits is $-0.29 \pm 0.06^{\circ} \mathrm{C}(\mathrm{C}-\mathrm{GLORSv} 7)$ and temperatures remain negative throughout the year. After passing through Baffin Bay, the volume export is $-2.3 \pm 0.4 \mathrm{~Sv}$. The difference between the volume transport through the Canadian Straits and through Davis Strait is as large as the temporal variability of each estimate (all are $0.4 \mathrm{~Sv}$ ). This argument is somewhat consistent with Curry et al. (2011), who argue that the 0.6 Sv discrepancy between Baffin Bay inflows (through the Canadian Straits and from freshwater sources including P-E, Baffin Island Runoff, and melting of CAA Ice and the Greenland Ice sheet) and Davis Strait export can be attributed to the uncertainties of the respective estimates. As a rough estimate for the contribution of terrestrial freshwater sources to Davis Strait exports, the 2007 - 2016 average freshwater input into Baffin Bay from solid and liquid discharge from the Greenland Ice sheet and terrestrial runoff from the ice sheet and the CAA was only $10 \mathrm{mSv}$ (or $314 \mathrm{~km} / \mathrm{yr}$ ), albeit with a clear upward trend in the past decades (Bamber et al., 2018). The contribution from P-E to the freshwater input into Baffin Bay was approximately $4 \mathrm{mSv}$ (or $130 \mathrm{~km}$ /yr) on average between 2000 and 2011 (based on ERA-Interim, Alkire et al., 2017).

We check the influence of the spatial coverage of C-GLORSv7 data on the transport estimates by choosing only one reanalysis transport point for each observational point (i.e. reducing C-GLORSv7 spatial coverage) and interpolating horizontally between them to the full cross-section grid. We conduct this analysis for Davis Strait, because the incorporation of model data into OBS is limited to the upper $100 \mathrm{~m}$ due to sufficient observational coverage in the remainder of Davis Strait (Tsubouchi et al., 2018). We obtain a volume transport estimate of $-2.3 \pm 0.6 \mathrm{~Sv}$, which compares well with the estimate obtained from full 
C-GLORSv7 resolution ( $-2.4 \pm 0.5 \mathrm{~Sv}$, derived from summing over the full cross-section). When reducing the resolution even further to half the observational points, the volume export becomes smaller (- $1.6 \pm 1.4 \mathrm{~Sv})$ than the original estimate. This suggests that the results quickly become rather sensitive to the exact choice of points if the resolution is further reduced. Whether the resolution of observations and model points is sufficient in a strait presumably depends on the heterogeneity of transports through each strait.

\subsection{Fram Strait}

The average volume export through Fram Strait as estimated from C-GLORSv7 (- $2.2 \pm 0.9 \mathrm{~Sv})$ is larger than the observationbased estimate ( $-1.1 \pm 1.2 \mathrm{~Sv}$, see Tab. 1) although the values agree within their respective temporal variability ranges. Similar to Davis Strait, we also give the uncertainty derived by Tsubouchi et al. (2012) for Summer 2005, when the net transport though Fram Strait was $-1.6 \pm 3.9$ Sv. Note the much larger relative uncertainty (244\%) compared to Davis Strait (23\%), which can be attributed to the larger cross-section area of Fram Strait on the one hand, and to the lack of observations over Belgica Bank on the other. Other model-based estimates of Fram Strait volume exports are similar to our C-GLORSv7 estimates: Fieg et al. (2010) calculated a transport of - $2.0 \pm 1.26 \mathrm{~Sv}$ based on a $1 / 12^{\circ}$ resolution model with 50 vertical levels and Zuo et al. (2011) reported - $2.5 \pm 0.5 \mathrm{~Sv}$ for the UR025.1 averaged over $1987-2004$, both estimates being closer to the C-GLORSv7 estimate than to the observation-based one. The long-term multi model mean from the model intercomparison study (Ilicak et al., 2016) was $-1.95 \mathrm{~Sv}$, which is very close to our reanalysis-based results. For the control experiment, we obtain - 1.8 $\pm 0.8 \mathrm{~Sv}$ (see Tab. 1) which is in perfect agreement with Zuo et al. (2011) who report - $1.8 \pm 0.5 \mathrm{~Sv}$ for their nonassimilating experiment.

More interesting than the total transport through Fram Strait are the contributions from the inflowing West Spitzbergen Current (WSC, east of $5^{\circ} \mathrm{E}$ or $\mathrm{d}=550$ to $685 \mathrm{~km}$ in Fig. 4) in the eastern part of the strait, and the East Greenland Current (EGC, 6.5 $\mathrm{W}$ to $2^{\circ} \mathrm{W}$ or $\mathrm{d}=305$ to $400 \mathrm{~km}$ ) on the western end of the deep basin. In OBS the WSC branch transports $6.4 \pm 0.9 \mathrm{~Sv}$ (Fig. 1) of relatively warm water $\left(1.0 \pm 0.2^{\circ} \mathrm{C}\right)$ northwards. In the reanalysis, the currents in this branch are weaker, transporting only $5.3 \pm 1.0 \mathrm{~Sv}$ of $0.9 \pm 0.1{ }^{\circ} \mathrm{C}$ warm water. The smaller northward volume transport is mainly due to the core of the WSC to the very East of Fram Strait (east of $8.2^{\circ} \mathrm{E}$ or $\left.\mathrm{d}=616 \mathrm{~km}\right)$ being weaker in the reanalysis $(0.7 \pm 0.2 \mathrm{~Sv})$ than in OBS $(1.6 \pm$ $0.4 \mathrm{~Sv}$ ). Based on the moored array in the WSC, Beszczynska-Möller et al. (2012) report a long-term (1997 - 2010) average volume transport of $6.6 \pm 0.4 \mathrm{~Sv}$ (with a contribution of $1.8 \pm 0.1 \mathrm{~Sv}$ from the core of the WSC), which is very close to the observation-based estimate from our study. Comparing the cross-sections of velocity and potential temperature (Fig. 4) from the observation-based dataset to the long-term observational cross-sections presented in Beszczynska-Möller et al. (2012) we generally find a very good agreement for both quantities. This gives confidence in the observation-based cross-sections and estimates presented here.

For the EGC, we calculate a southward flow $\left(-6.1 \pm 1.2 \mathrm{~Sv}\right.$ ) of $-0.02 \pm 0.10^{\circ} \mathrm{C}$ water for OBS. For the reanalysis, the volume 
export is again weaker (- $4.6 \pm 0.9 \mathrm{~Sv})$. Both of our estimates are lower than the longer-term $(2002-2009)$ observation-based estimate of $-8.7 \pm 2.5 \mathrm{~Sv}$ presented by de Steur et al. (2014), although a direct comparison is not possible as the EGC is defined from $6.5^{\circ} \mathrm{W}$ to $1^{\circ} \mathrm{W}$ in their study, whereas we integrate to $2^{\circ} \mathrm{W}$ (following Tsubouchi et al., 2012). Velocities between $2^{\circ} \mathrm{W}$ and $1^{\circ} \mathrm{W}$ are negative in the annual mean, so a larger export is to be expected when including this region in the integral. Both velocity and temperature distributions across the strait from OBS agree well with the $2002-2009$ annual mean cross-sections presented in de Steur et al. (2014). The average temperature in this branch is fairly constant $\left(-0.00 \pm 0.06{ }^{\circ} \mathrm{C}\right)$. In the reanalysis, the southward current is stronger in the upper $100 \mathrm{~m}$, but is limited to a narrower region overall, resulting in a weaker volume export. Data-assimilation affects the strength of the two branches, making them stronger compared to the control experiment (WSC: $2.4 \pm 1.0 \mathrm{~Sv}$, EGC: $-3.1 \pm 1.0 \mathrm{~Sv}$ ). In contrast to Davis Strait, the assimilating reanalysis experiment exhibits a stronger horizontal temperature gradient than the control experiment in the upper $800 \mathrm{~m}$, which implies higher velocities in the upper ocean. The agreement with the observation-based estimate is also better for the temperature distribution in Fram Strait in the assimilating experiment compared to the control.

Even though there are several moorings in Fram Strait (see Fig. 4a), some of the instruments failed to record data during the study period (see supporting information of Tsubouchi et al., 2018). This is especially true for the easternmost part of Fram Strait (core of the WSC), the eastern boundary of the EGC and the upper ocean. The disagreement between the reanalysis and the observation-based velocities is largest in those regions, as is the temperature disagreement in the upper ocean.

Our results for the roughly $1 \mathrm{~Sv}$ weaker WSC and EGC transports in the reanalysis compared to observations are qualitatively in line with Ilicak et al. (2016), who found that the models typically underestimate the strength of the inflowing and outflowing branches. Fieg et al. (2010) also pointed out that many ice-ocean models have weaker volume and temperature imports and exports in Fram Strait compared to observation-based estimates. The latter attributed the underrepresentation of Fram Strait currents to the recirculation, which in the models occurs further south than observed. Fahrbach et al. (2001) estimated that 2.6 $\pm 0.1 \mathrm{~Sv}$ are transported westward between $78.50^{\circ} \mathrm{N}$ and $79^{\circ} \mathrm{N}$. As previously discussed by de Steur et al. (2014), the strength of the observed East Greenland Current is highly sensitive to the latitudinal position of the moorings. A relocation of the moored array in 2002 from $79^{\circ} \mathrm{N}$ to $78.5^{\circ} \mathrm{N}$ lead to an increase in the observed volume transport of almost $3 \mathrm{~Sv}$ compared to the years preceding the southward shift.

The representation of the recirculation in ocean models is also highly dependent on the horizontal resolution, as Fieg et al. (2010) discuss that their $1 / 4^{\circ}$ model does not capture the recirculation, whereas their $1 / 12^{\circ}$ model does. This is further supported by Hattermann et al. (2016), who used a high resolution model with $800 \mathrm{~m}$ grid spacing to study the contribution of mesoscale eddies to the recirculation of Atlantic Water in Fram Strait. They found that mesoscale eddies contribute significantly to the recirculation, which is especially strong during winter and spring, when eddies divert the WSC westward, just North of the moored array. Furthermore, the cyclonic Molloy Hole gyre to the North of the moored array seems to efficiently transport warm eddies from the WSC to the EGC (Hattermann et al., 2016). In conclusion, it seems likely that the 
horizontal resolution of C-GLORSv7 $\left(1 / 4^{\circ}, \sim 10 \mathrm{~km}\right)$ is too low to capture mesoscale eddies in Fram Strait (the typical Rossby radius is $3-6 \mathrm{~km}$ in the WSC, Appen et al., 2016). The recirculation is therefore likely underrepresented in our reanalysis, as indicated by the weak volume transports in the WSC and EGC. However, the net volume transport is not affected as strongly by this shortcoming as the two branches are individually, since the discrepancies in the inflowing WSC and outflowing EGC at least partly compensate each other concerning the total transport.

\subsection{Barents Sea Opening}

The volume transport calculated from the reanalysis fields is greater $(3.4 \pm 1.1 \mathrm{~Sv}$, C-GLORSv7) than the observation-based estimate ( $2.3 \pm 1.2 \mathrm{~Sv}$, Tab. 1) throughout the entire study period. As mentioned already in Sect. 4.1, volume transports through the BSO were particularly high during our study period, exceeding the $1997-2006$ average of $1.8 \mathrm{~Sv}$ almost during the entire year despite the large seasonal cycle (Skagseth et al., 2008). The updated transport estimate for $1997-2007$ was $2.0 \mathrm{~Sv}$ (Smedsrud et al., 2010). Comparing C-GLORSv7 to OBS, we find similar cross-section average temperatures $\left(4.5 \pm 2.8^{\circ} \mathrm{C}\right.$ in OBS, $4.3 \pm 2.3^{\circ} \mathrm{C}$ in C-GLORSv7) and temperatures are greater than zero throughout the year in the majority of the BSO. The only region where temperatures are negative during the winter months is North of Bear Island. The average volume transports through this part of the section is small (0.04 $\pm 0.20 \mathrm{~Sv}$ from C-GLORSv7).

Volume transports are greater in C-GLORSv7 and in C-GLORSv7 control compared to OBS, by approximately 1-2 Sv throughout the study period. In order to provide some information on the uncertainty of OBS, we cite the Summer 2005 transport estimate including the a posteriori uncertainty 3.6 $\pm 1.1 \mathrm{~Sv}$ from Tsubouchi et al. (2012). We also compare our reanalysis results to Ilicak et al. (2016), who obtained a multi model mean of $2.53 \mathrm{~Sv}$. This value is closer to the OBS estimate, although if the average were taken over a shorter, more recent period of time the value would likely be higher, due to a clear upward trend in $\mathrm{F}_{\mathrm{V}}$ (consistent with Skagseth et al., 2008) beginning as early as 1970 in some of the models. Our volume transport estimate from the reanalysis $(3.4 \pm 1.1 \mathrm{~Sv}$ for C-GLORSv7 and $3.3 \pm 1.0 \mathrm{~Sv}$ for the control experiment) compare well to Zuo et al. (2011) who report a transport of $3.4 \pm 0.3 \mathrm{~Sv}$ for the full experiment and $3.0 \pm 0.2 \mathrm{~Sv}$ for the control (both are the $1987-2004$ average). In our case the full experiment has higher cross-section average temperatures $\left(4.3 \pm 0.5^{\circ} \mathrm{C}\right)$ compared to the control experiment $\left(3.9 \pm 0.6^{\circ} \mathrm{C}\right)$. In the $\mathrm{BSO}$, data assimilation increases the agreement in the temperature cross-sections between the reanalysis and OBS. The improvement in temperature distributions is not surprising, since both OBS and C-GLORS incorporate vessel based CTD data from several cruises in this strait.

Roughly one third of the discrepancy between the reanalysis and observation-based data concerning BSO volume transports can be attributed to the individual representation of the flow in the Bear Island Channel (BIC, $d=360-470 \mathrm{~km}$ in Fig. 5 or $74.3^{\circ} \mathrm{N}$ to $73.4^{\circ} \mathrm{N}$ ). As discussed by Smedsrud et al. (2010), Fv through the BSO south of Bear Island consists of an inflowing branch of roughly $3.2 \mathrm{~Sv}$ and an outflowing branch in the BIC. From the one year of OBS, we estimate the strength of this 
outflowing current to be $-0.34 \pm 0.60 \mathrm{~Sv}$ (Fig. 1), which is considerably smaller than the previous estimate of - $1.2 \mathrm{~Sv}$ derived from in-situ observations between 09/1978 - 01/1979 (Blindheim, 1989). This weaker export might, at least partly, be explained by the inter-annual variability of the BSO flow driven by variations in the local wind field (Ingvaldsen, 2005). In contrast to OBS and literature estimates the C-GLORSv7 volume flow in the BIC is eastward ( $0.32 \pm 0.26 \mathrm{~Sv})$ throughout the entire study period, except for a negligible export of $<2 \mathrm{mSv}$ in December 2005. In both the assimilating and the control reanalysis experiments the average volume transport is positive in the BIC. On a side note, the velocity cross-sections based on OBS reveal an eastward transport in parts of the BIC between January and March, as well as in September and June. This leads to a high temporal variability of the OBS Fv estimate through the BIC. Ingvaldsen (2005) also mentioned that Arctic inflow in this region is to be expected during winter. $\mathrm{F}_{\mathrm{V}}$ through the remaining BSO south of Bear Island is $2.4 \pm 0.9 \mathrm{~Sv}$ (OBS). In CGLORSv7 the transport estimate is $3.0 \pm 0.8 \mathrm{~Sv}$. We estimate that $28 \%$ of the discrepancy in $\mathrm{F}_{\mathrm{V}}$ are attributable to the BIC, despite the fact that it covers only $15 \%$ of the BSO cross-section area.

Due to the relatively low resolution of our reanalysis compared to the small Rossby radius in this shallow strait $(\sim 2 \mathrm{~km}$, Dupont et al., 2015), eddy driven features such as the Norwegian Coastal Current (Wekerle et al., 2017) which is located in the very South of the strait (South of $71.4^{\circ} \mathrm{N}$, Tsubouchi et al., 2012, corresponding to $\sim 700 \mathrm{~km}$ to the end of the strait in Fig. 5) are likely to be underrepresented in the reanalysis ( $0.9 \pm 0.3 \mathrm{~Sv}, \mathrm{C}-$ GLORSv7, Fig. 1). Skagseth et al. (2011) estimated the strength of this current to be $1.8 \mathrm{~Sv}$. This is larger than our estimate of $0.7 \pm 0.2 \mathrm{~Sv}$ (OBS) for the study period, which is at least partly due to the fact that there are no observations in this area.

\subsection{Bering Strait}

Disagreement is detected in the net $\mathrm{F}_{\mathrm{V}}$ estimates $(1.0 \pm 0.6 \mathrm{~Sv}$ from C-GLORSv7 versus $0.7 \pm 0.7 \mathrm{~Sv}$ from OBS, Tab. 1) through Bering Strait, although the values lie within each other's temporal variability range. The transport and uncertainty estimate for Summer 2005 was $1.0 \pm 0.2 \mathrm{~Sv}$ (Tsubouchi et al., 2012). Our reanalysis based estimate is equal to the long-term multi-model mean transport estimate of $0.99 \mathrm{~Sv}$ (Ilicak et al., 2016). It also lies perfectly within the range (0.67 Sv - 1.29 Sv, 1979 - 2004 mean) of volume transports estimated from five models with different resolutions (Clement Kinney et al., 2014).

The observed volume transport through Bering Strait was low during 2005 (see Sect. 4.1), but generally transports increased from about $0.7 \mathrm{~Sv}$ in 2001 to roughly 2.1 Sv in 2014 (Woodgate, 2018). The horizontal resolution of our reanalysis product is about $13 \mathrm{~km}$ in Bering Strait, which is much larger than the Rossby radius of about $2 \mathrm{~km}$ (Dupont et al., 2015), and thus it is not able to capture small-scale features such as mesoscale eddies (Clement Kinney et al., 2014).

The high temporal variability of cross-section average temperatures (December to February: $-1.8 \pm 0.0^{\circ} \mathrm{C}$ from OBS, $-1.2 \pm$ $0.2{ }^{\circ} \mathrm{C}$ from C-GLORSv7, June to August: $1.3 \pm 1.3{ }^{\circ} \mathrm{C}$ from OBS and $2.7 \pm 1.4{ }^{\circ} \mathrm{C}$ from C-GLORSv7) and volume transports (December to February: $0.3 \pm 0.8 \mathrm{~Sv}$ from OBS and $0.7 \pm 0.6 \mathrm{~Sv}$ from C-GLORSv7, June to August: $1.3 \pm 0.2$ from OBS and 
$1.4 \pm 0.1 \mathrm{~Sv}$ from C-GLORSv7) is in agreement with Woodgate et al. (2005). Volume transports are higher during the study period in C-GLORS (in both experiments).

During the summer months June to August, the vertical distribution of temperatures is relatively homogeneous in OBS, whereas the ocean is clearly stratified in the reanalysis (see Fig. 7). This is attributed to the fact that the shallowest instruments measuring temperature in this strait are located at $35 \mathrm{~m}$ depth (see Fig. 6 - 7). Woodgate et al. (2010) mentioned the presence of a warm surface layer in Bering Strait during summer and that the average cross-section temperatures are underestimated when using only near-bottom measurements. Therefore, confidence is higher in the Bering Strait temperature distribution derived from C-GLORSv7 than from the mooring-based dataset. During the winter months, the temperature distribution is almost uniform across the strait in both datasets, which is in accordance with Woodgate et al. (2005a), who reported a wellmixed water column during autumn/winter.

Data-assimilation in this strait has almost no influence on the volume transport (1.0 $\pm 0.5 \mathrm{~Sv}$ from the control experiment) in the CGLORSv7 reanalysis. Zuo et al. (2011) calculate the Bering Strait volume transport to be $1.3 \pm 0.1 \mathrm{~Sv}$ for both the control experiment and the full UR025.1. They also mention that the small influence of data assimilation is not surprising considering the relatively limited observational coverage.

\section{Conclusion}

Summarizing the results from our comparison of the CMCC Global Ocean Physical Reanalysis System (C-GLORS version 7) with observation-based (OBS) estimates in the Arctic gateways, we first note that the net horizontal volume transport estimates are a factor five smaller in C-GLORSv7 $(-0.03 \pm 0.23 \mathrm{~Sv})$ than in OBS $(-0.15 \pm 0.06 \mathrm{~Sv})$. The average net heat transport into the Arctic Ocean from the two datasets agrees very well and is close to $150 \mathrm{TW}$ (153 \pm 44 TW from the observation-based data and $145 \pm 35$ from C-GLORSv7). The net heat transport during our study period may have been higher than the longterm average, as discussed in Sect. 4.1.

Looking in more detail at the comparisons in the individual straits, we find good agreement in Davis Strait volume transports (- $2.3 \pm 0.4 \mathrm{~Sv}$ from C-GLORSv7 versus $-2.1 \pm 0.7 \mathrm{~Sv}$ from OBS). There is a small volume export in the reanalysis in the warm eastern Davis Strait (east of $d=200 \mathrm{~km}$ in Fig. 3a). In contrast, currents are northward in this area in OBS, in accordance with Beszczynska-Möller et al. (2011). Compared to the full reanalysis resolution, the volume transport estimates for Davis Strait are not significantly altered when reducing the horizontal resolution of C-GLORSv7 data to the instrument locations. However, if the reanalysis resolution is reduced even further, the estimates start to differ notably $(-1.6 \pm 1.4 \mathrm{~Sv}$ when using only half of the instrument locations in the reanalysis).

The volume transports through the Canadian Straits (Lancaster Sound, Nares Strait and Hell Gate/Cardigan Strait) are 
estimated to have been - $1.9 \pm 0.4 \mathrm{~Sv}$ during our study period from September 2005 to August 2006, based on C-GLORSv7. We find weaker inflowing and outflowing currents in Fram Strait in the reanalysis compared to the observation-based estimate. The strength of the northward West Spitzbergen Current in the eastern part of Fram Strait is about $1 \mathrm{~Sv}$ greater in the observation-based data ( $6.4 \pm 0.9 \mathrm{~Sv})$ compared to the reanalysis (5.3 $\pm 1.0 \mathrm{~Sv}$, C-GLORSv7). The export in the East Greenland Current at the western end of deep Fram Strait is $-6.1 \pm 1.2 \mathrm{~Sv}$ in the observation-based data, which is again larger than in the reanalysis (- $4.6 \pm 0.9 \mathrm{~Sv}, \mathrm{C}$-GLORSv7). The agreement in the strength of those two branches is better in C-GLORSv7 compared to the control experiment, which seems to be related to a stronger horizontal temperature gradient in the assimilating experiment.

For the Barents Sea Opening, our transport estimates from C-GLORSv7 (3.4 $\pm 1.1 \mathrm{~Sv})$ are greater than in the observationbased estimate $(2.3 \pm 1.2 \mathrm{~Sv})$. The greater volume transports are at least partly due to currents in the Bear Island Channel flowing eastwards in the reanalysis (in both reanalysis versions with and without data assimilation), whereas they are westward in OBS. This observation-based export is qualitatively in line with previous descriptions of Barents Sea Opening currents (Smedsrud et al., 2010), albeit the transport through the Bear Island Channel is weaker (- $0.34 \pm 0.60 \mathrm{~Sv})$ in our study than the 1.2 Sv reported by Blindheim (1989). Neither the observation-based dataset nor the reanalysis are likely to capture the full transport through the Norwegian Coastal Current in the very South of the Strait $(0.7 \pm 0.2 \mathrm{~Sv}$ from OBS, $0.9 \pm 0.3 \mathrm{~Sv}$ from CGLORSv7, compared to 1.8 Sv from Skagseth et al., 2011). Based on the C-GLORSv7 reanalysis, we estimate that the flow north of Bear Island is small but with a high temporal variability $(0.04 \pm 0.20 \mathrm{~Sv})$. In this strait, data assimilation improves the agreement between the observation-based data and C-GLORS concerning the temperature distribution. This is not surprising, since vessel-based hydrographic observations are incorporated in both datasets. Finally, the observation-based estimate of Bering Strait volume transports is significantly weaker in the observation-based dataset $(0.7 \pm 0.7 \mathrm{~Sv})$ compared to the reanalysis $(1.0 \pm 0.6 \mathrm{~Sv}, \mathrm{C}-\mathrm{GLORSv} 7)$.

We find that the disagreement between the reanalysis and OBS is often associated with regions where in-situ observations are lacking (either because of the absence of instruments or due to instrumental failure during the study period). This is evident in Bering Strait during summer, when the observation-based dataset shows no sign of stratification due to the lack of measurements close to the surface. Similarly, the region North of Bear Island where there are no in-situ observations shows discrepancies in the Barents Sea Opening cross-sections, as does the unobserved Belgica Bank in Fram Strait. Even though most parts of Fram Strait and Davis Strait have quite a high instrumental coverage, some of the regions were poorly observed during the study period due to instrumental failures (see supporting information of Tsubouchi et al., 2018). The eastern boundary of the East Greenland Current and the very East of Fram Strait, but also close to Baffin Island in Davis Strait are examples where the discrepancies in the velocity cross-sections are co-located with sparse data recording during the study period. Both the reanalysis and observation-based dataset would benefit from additional observations, but the Arctic Gateways, especially close to the sea surface, are very challenging and expensive to observe (Beszczynska-Möller et al., 2011). We 
therefore hope that our study will be helpful in the planning of upcoming reanalysis products and future additions to the observational network in the Arctic Ocean.

In conclusion, both the reanalysis and the observation-based dataset have their advantages and disadvantages. The results from our study provide useful insight into the reliability of a state-of-the-art ocean reanalysis and of a new, comprehensive observation-based dataset. This can contribute to the planning of future observational efforts and to develop ocean reanalysis products. In regions where agreement between the two datasets is good, they reinforce each other. This includes the velocity distribution in large parts of the Barents Sea Opening and Bering Strait, but also the temperature distribution in Fram Strait. However, there is a large discrepancy in the net volume transport into the Arctic Ocean, but also in regions where observations are lacking or where one of the two datasets is performing poorly compared to previously published estimates. This includes the Eastern Davis Strait, where we find a weak volume export in the reanalysis instead of inflows (as seen in the observationbased dataset and in other studies), or the discrepancy between the reanalysis and the observation-based dataset concerning the strength of the East Greenland Current and West Spitzbergen Current in Fram Strait. It also includes the lack of stratification during Summer in Bering Strait in the observation-based dataset and the inflowing instead of outflowing current in the reanalysis in the Bear Island Channel.

One distinct merit of ocean reanalyses is that they provide an important source of information about the state of the ocean where observations are lacking, for example North of the Arctic Gateways. We therefore recommend considering volume transports as well as velocity and temperature distributions from an ocean reanalysis and in-situ observations where the latter are available using comparative tools like the ones presented in this study. From this comparison, one can then infer the reliability of the reanalysis product for climate studies in data-sparse regions. The present study is also a demonstration of how observation-based data could be used routinely by reanalysis producers to assess the performance of their products in the Arctic. We plan to compare C-GLORS for a longer time period (2004 - 2010) as soon as the corresponding observation-based data become available. This comparison will give insight into discrepancies between the two datasets concerning the seasonal cycles and temporal variability of temperature, velocities and associated transports. 


\section{Data Availability}

The observation-based data are available through PANGAEA (Tsubouchi et al., 2017). The C-GLORS v5 and v7 data can be obtained from CMCC upon registration at http://c-glors.cmcc.it/.

\section{Supplement link}

The conclusions presented in this paper are supported by the figures and tables in the main text. Additional figures supporting the methods can be found in the supplementary material.

\section{Author Contribution}

All authors contributed significantly to this study and to the preparation of this manuscript. Marianne Pietschnig wrote the code for this study and prepared the manuscript with inputs from all authors. Michael Mayer and Leopold Haimberger provided essential expertise on the coupled atmosphere-sea ice-ocean system and how to best analyse the results. Sebastian Stichelberger helped with the preparation of figures. Andrea Storto provided expert knowledge on the ocean reanalysis and Takamasa Tsubouchi on the observation-based dataset as well as on the physical oceanography of the Arctic.

\section{Competing Interests}

The authors declare that they have no conflict of interest.

\section{Acknowledgements}

This study was funded by the Austrian Science Fund project P28818 and by ERA-CLIM2 (EU FP7 grant No. 607029). Takamasa Tsubouchi's involvement was supported by the EU's Horizon 2020 Marie Skłodowska-Curie grant agreement No. 652757. The production of C-GLORS is funded through the Copernicus Marine Environment Monitoring Service (CMEMS) of the Copernicus European Union Programme. 


\section{References}

Alkire, M. B., Morison, J., Schweiger, A., Zhang, J., Steele, M., Peralta-Ferriz, C. and Dickinson, S.: A Meteoric Water Budget for the Arctic Ocean: ARCTIC MW BUDGET, J. Geophys. Res. Oceans, 122(12), 10020-10041, doi:10.1002/2017JC012807, 2017.

Appen, W.-J. von, Schauer, U., Hattermann, T. and Beszczynska-Möller, A.: Seasonal Cycle of Mesoscale Instability of the West Spitsbergen Current, J. Phys. Oceanogr., 46(4), 1231-1254, doi:10.1175/JPO-D-15-0184.1, 2016.

Årthun, M., Eldevik, T., Smedsrud, L. H., Skagseth, $\varnothing$. and Ingvaldsen, R. B.: Quantifying the Influence of Atlantic Heat on Barents Sea Ice Variability and Retreat*, J. Clim., 25(13), 4736-4743, doi:10.1175/JCLI-D-11-00466.1, 2012.

Bacon, S., Marshall, A., Holliday, N. P., Aksenov, Y. and Dye, S. R.: Seasonal variability of the East Greenland Coastal Current, J. Geophys. Res. Oceans, 119(6), 3967-3987, doi:10.1002/2013JC009279, 2014.

Bacon, S., Aksenov, Y., Fawcett, S. and Madec, G.: Arctic mass, freshwater and heat fluxes: methods and modelled seasonal variability, Philos. Trans. R. Soc. Math. Phys. Eng. Sci., 373(2052), 20140169, doi:10.1098/rsta.2014.0169, 2015.

Balmaseda, M. A., Mogensen, K. and Weaver, A. T.: Evaluation of the ECMWF ocean reanalysis system ORAS4, Q. J. R. Meteorol. Soc., 139(674), 1132-1161, doi:10.1002/qj.2063, 2013.

Bamber, J. L., Tedstone, A. J., King, M. D., Howat, I. M., Enderlin, E. M., van den Broeke, M. R. and Noel, B.: Land Ice Freshwater Budget of the Arctic and North Atlantic Oceans: 1. Data, Methods, and Results, J. Geophys. Res. Oceans, 123(3), 1827-1837, doi:10.1002/2017JC013605, 2018.

Bernard, B., Madec, G., Penduff, T., Molines, J.-M., Treguier, A.-M., Le Sommer, J., Beckmann, A., Biastoch, A., Böning, C., Dengg, J., Derval, C., Durand, E., Gulev, S., Remy, E., Talandier, C., Theetten, S., Maltrud, M., McClean, J. and De Cuevas, B.: Impact of partial steps and momentum advection schemes in a global ocean circulation model at eddy-permitting resolution, Ocean Dyn., 56(5-6), 543-567, doi:10.1007/s10236-006-0082-1, 2006.

Beszczynska-Möller, A., Woodgate, R., Lee, C., Melling, H. and Karcher, M.: A Synthesis of Exchanges Through the Main Oceanic Gateways to the Arctic Ocean, Oceanography, 24(3), 82-99, doi:10.5670/oceanog.2011.59, 2011.

Beszczynska-Möller, A., Fahrbach, E., Schauer, U. and Hansen, E.: Variability in Atlantic water temperature and transport at the entrance to the Arctic Ocean, 1997-2010, ICES J. Mar. Sci., 69(5), 852-863, doi:10.1093/icesjms/fss056, 2012.

Blindheim, J.: Cascading of Barents Sea bottom water into the Norwegian Sea, Rapp P-V 693 Réun Cons Int Explor Mer, 188, 1989.

Bouillon, S., Morales Maqueda, M. Á., Legat, V. and Fichefet, T.: An elastic-viscous-plastic sea ice model formulated on Arakawa B and C grids, Ocean Model., 27(3-4), 174-184, doi:10.1016/j.ocemod.2009.01.004, 2009.

Burgard, C. and Notz, D.: Drivers of Arctic Ocean warming in CMIP5 models, Geophys. Res. Lett., 44(9), 4263-4271, doi:10.1002/2016GL072342, 2017.

Carmack, E. C., Yamamoto-Kawai, M., Haine, T. W. N., Bacon, S., Bluhm, B. A., Lique, C., Melling, H., Polyakov, I. V., Straneo, F., Timmermans, M.-L. and Williams, W. J.: Freshwater and its role in the Arctic Marine System: Sources, disposition, storage, export, and physical and biogeochemical consequences in the Arctic and global oceans, J. Geophys. Res. Biogeosciences, 121(3), 675-717, doi:10.1002/2015JG003140, 2016. 
Clement Kinney, J., Maslowski, W., Aksenov, Y., de Cuevas, B., Jakacki, J., Nguyen, A., Osinski, R., Steele, M., Woodgate, R. A. and Zhang, J.: On the Flow Through Bering Strait: A Synthesis of Model Results and Observations, in The Pacific Arctic Region, edited by J. M. Grebmeier and W. Maslowski, pp. 167-198, Springer Netherlands, Dordrecht., 2014.

Comiso, J. C., Parkinson, C. L., Gersten, R. and Stock, L.: Accelerated decline in the Arctic sea ice cover, Geophys. Res. Lett., 35(1), doi:10.1029/2007GL031972, 2008.

Curry, B., Lee, C. M. and Petrie, B.: Volume, Freshwater, and Heat Fluxes through Davis Strait, 2004-05*, J. Phys. Oceanogr., 41(3), 429-436, doi:10.1175/2010JPO4536.1, 2011.

Curry, B., Lee, C. M., Petrie, B., Moritz, R. E. and Kwok, R.: Multiyear Volume, Liquid Freshwater, and Sea Ice Transports through Davis Strait, 2004-10*, J. Phys. Oceanogr., 44(4), 1244-1266, doi:10.1175/JPO-D-13-0177.1, 2014.

Dee, D. P., Uppala, S. M., Simmons, A. J., Berrisford, P., Poli, P., Kobayashi, S., Andrae, U., Balmaseda, M. A., Balsamo, G., Bauer, P., Bechtold, P., Beljaars, A. C. M., van de Berg, L., Bidlot, J., Bormann, N., Delsol, C., Dragani, R., Fuentes, M., Geer, A. J., Haimberger, L., Healy, S. B., Hersbach, H., Hólm, E. V., Isaksen, L., Kållberg, P., Köhler, M., Matricardi, M., McNally, A. P., Monge-Sanz, B. M., Morcrette, J.-J., Park, B.-K., Peubey, C., de Rosnay, P., Tavolato, C., Thépaut, J.-N. and Vitart, F.: The ERA-Interim reanalysis: configuration and performance of the data assimilation system, Q. J. R. Meteorol. Soc., 137(656), 553-597, doi:10.1002/qj.828, 2011.

Desroziers, G., Berre, L., Chapnik, B. and Poli, P.: Diagnosis of observation, background and analysis-error statistics in observation space, Q. J. R. Meteorol. Soc., 131(613), 3385-3396, doi:10.1256/qj.05.108, 2005.

Dickson, R. G. B., Meincke, J. and Rhines, P., Eds.: Arctic-subarctic ocean fluxes: defining the role of the northern seas in climate, Springer, Dordrecht., 2008.

Drange, H., Gerdes, R., Gao, Y., Karcher, M., Kauker, F. and Bentsen, M.: Ocean general circulation modelling of the Nordic seas, in Geophysical Monograph Series, vol. 158, pp. 199-219, American Geophysical Union, Washington, D. C., 2005.

Dupont, F., Higginson, S., Bourdallé-Badie, R., Lu, Y., Roy, F., Smith, G. C., Lemieux, J.-F., Garric, G. and Davidson, F.: A high-resolution ocean and sea-ice modelling system for the Arctic and North Atlantic oceans, Geosci. Model Dev., 8(5), 15771594, doi:10.5194/gmd-8-1577-2015, 2015.

Fahrbach, E., Meincke, J., Østerhus, S., Rohardt, G., Schauer, U., Tverberg, V. and Verduin, J.: Direct measurements of volume transports through Fram Strait, Polar Res., 20(2), 217-224, doi:10.1111/j.1751-8369.2001.tb00059.x, 2001.

Fichefet, T. and Maqueda, M. A. M.: Sensitivity of a global sea ice model to the treatment of ice thermodynamics and dynamics, J. Geophys. Res. Oceans, 102(C6), 12609-12646, doi:10.1029/97JC00480, 1997.

Fieg, K., Gerdes, R., Fahrbach, E., Beszczynska-Möller, A. and Schauer, U.: Simulation of oceanic volume transports through Fram Strait 1995-2005, Ocean Dyn., 60(3), 491-502, doi:10.1007/s10236-010-0263-9, 2010.

Good, S. A., Martin, M. J. and Rayner, N. A.: EN4: Quality controlled ocean temperature and salinity profiles and monthly objective analyses with uncertainty estimates, J. Geophys. Res. Oceans, 118(12), 6704-6716, doi:10.1002/2013JC009067, 2013.

Haine, T. W. N., Curry, B., Gerdes, R., Hansen, E., Karcher, M., Lee, C., Rudels, B., Spreen, G., de Steur, L., Stewart, K. D. and Woodgate, R.: Arctic freshwater export: Status, mechanisms, and prospects, Glob. Planet. Change, 125, 13-35, doi:10.1016/j.gloplacha.2014.11.013, 2015. 
Hattermann, T., Isachsen, P. E., von Appen, W.-J., Albretsen, J. and Sundfjord, A.: Eddy-driven recirculation of Atlantic Water in Fram Strait: Eddy-Driven Recirculation in Fram Strait, Geophys. Res. Lett., 43(7), 3406-3414, doi:10.1002/2016GL068323, 2016.

Ilıcak, M., Drange, H., Wang, Q., Gerdes, R., Aksenov, Y., Bailey, D., Bentsen, M., Biastoch, A., Bozec, A., Böning, C., Cassou, C., Chassignet, E., Coward, A. C., Curry, B., Danabasoglu, G., Danilov, S., Fernandez, E., Fogli, P. G., Fujii, Y., Griffies, S. M., Iovino, D., Jahn, A., Jung, T., Large, W. G., Lee, C., Lique, C., Lu, J., Masina, S., George Nurser, A. J., Roth, C., Salas y Mélia, D., Samuels, B. L., Spence, P., Tsujino, H., Valcke, S., Voldoire, A., Wang, X. and Yeager, S. G.: An assessment of the Arctic Ocean in a suite of interannual CORE-II simulations. Part III: Hydrography and fluxes, Ocean Model., 100, 141-161, doi:10.1016/j.ocemod.2016.02.004, 2016.

Ingvaldsen, R. B.: Width of the North Cape Current and location of the Polar Front in the western Barents Sea, Geophys. Res. Lett., 32(16), doi:10.1029/2005GL023440, 2005.

Ingvaldsen, R. B., Asplin, L. and Loeng, H.: The seasonal cycle in the Atlantic transport to the Barents Sea during the years 1997-2001, Cont. Shelf Res., 24(9), 1015-1032, doi:10.1016/j.csr.2004.02.011, 2004.

Kawasaki, T. and Hasumi, H.: The inflow of Atlantic water at the Fram Strait and its interannual variability, J. Geophys. Res. Oceans, 121(1), 502-519, doi:10.1002/2015JC011375, 2016.

Kwok, R. and Rothrock, D. A.: Decline in Arctic sea ice thickness from submarine and ICESat records: 1958-2008, Geophys. Res. Lett., 36(15), doi:10.1029/2009GL039035, 2009.

Large, W. G. and Yeager, S. G.: The global climatology of an interannually varying air-sea flux data set, Clim. Dyn., 33(23), 341-364, doi:10.1007/s00382-008-0441-3, 2009.

Le Traon, P.-Y. and Ogor, F.: ERS-1/2 orbit improvement using TOPEX/POSEIDON: The $2 \mathrm{~cm}$ challenge, J. Geophys. Res. Oceans, 103(C4), 8045-8057, doi:10.1029/97JC01917, 1998.

Madec, G.: NEMO Ocean Engine, Note du Pole de modélisation 27, [online] Available from: http://www.nemoocean.eu/About-NEMO/Reference-manuals/NEMO_book_3.6_STABLE, 2008.

Marzocchi, A., Hirschi, J. J.-M., Holliday, N. P., Cunningham, S. A., Blaker, A. T. and Coward, A. C.: The North Atlantic subpolar circulation in an eddy-resolving global ocean model, J. Mar. Syst., 142, 126-143, doi:10.1016/j.jmarsys.2014.10.007, 2015.

Masina, S., Di Pietro, P., Storto, A. and Navarra, A.: Global ocean re-analyses for climate applications, Dyn. Atmospheres Oceans, 52(1-2), 341-366, doi:10.1016/j.dynatmoce.2011.03.006, 2011.

Mayer, M., Haimberger, L., Pietschnig, M. and Storto, A.: Facets of Arctic energy accumulation based on observations and reanalyses 2000-2015, Geophys. Res. Lett., 43(19), 10,420-10,429, doi:10.1002/2016GL070557, 2016.

Melling, H., Agnew, T. A., Falkner, K. K., Greenberg, D. A., Lee, C. M., Münchow, A., Petrie, B., Prinsenberg, S. J., Samelson, R. M. and Woodgate, R. A.: Fresh-Water Fluxes via Pacific and Arctic Outflows Across the Canadian Polar Shelf, in ArcticSubarctic Ocean Fluxes: Defining the Role of the Northern Seas in Climate, edited by R. R. Dickson, J. Meincke, and P. Rhines, pp. 193-247, Springer Netherlands, Dordrecht., 2008.

Münchow, A.: Volume and Freshwater Flux Observations from Nares Strait to the West of Greenland at Daily Time Scales from 2003 to 2009, J. Phys. Oceanogr., 46(1), 141-157, doi:10.1175/JPO-D-15-0093.1, 2016. 
Parkinson, C. L. and Comiso, J. C.: On the 2012 record low Arctic sea ice cover: Combined impact of preconditioning and an August storm, Geophys. Res. Lett., 40(7), 1356-1361, doi:10.1002/grl.50349, 2013.

Peixoto, J. P. and Oort, A. H.: Physics of climate, American Institute of Physics, New York., 1992.

Penduff, T., Juza, M., Brodeau, L., Smith, G. C., Barnier, B., Molines, J.-M., Treguier, A.-M. and Madec, G.: Impact of global ocean model resolution on sea-level variability with emphasis on interannual time scales, Ocean Sci., 6(1), 269-284, doi:10.5194/os-6-269-2010, 2010.

Peterson, I., Hamilton, J., Prinsenberg, S. and Pettipas, R.: Wind-forcing of volume transport through Lancaster Sound, J. Geophys. Res. Oceans, 117(C11), doi:10.1029/2012JC008140, 2012.

Reynolds, R. W., Smith, T. M., Liu, C., Chelton, D. B., Casey, K. S. and Schlax, M. G.: Daily High-Resolution-Blended Analyses for Sea Surface Temperature, J. Clim., 20(22), 5473-5496, doi:10.1175/2007JCLI1824.1, 2007.

Schauer, U. and Beszczynska-Möller, A.: Problems with estimation and interpretation of oceanic heat transport - conceptual remarks for the case of Fram Strait in the Arctic Ocean, Ocean Sci., 5(4), 487-494, doi:10.5194/os-5-487-2009, 2009.

Serreze, M. C., Barrett, A. P., Slater, A. G., Steele, M., Zhang, J. and Trenberth, K. E.: The large-scale energy budget of the Arctic, J. Geophys. Res., 112(D11), doi:10.1029/2006JD008230, 2007.

Serreze, M. C., Barrett, A. P., Stroeve, J. C., Kindig, D. N. and Holland, M. M.: The emergence of surface-based Arctic amplification, The Cryosphere, 3(1), 11-19, doi:10.5194/tc-3-11-2009, 2009.

Skagseth, Ø., Furevik, T., Ingvaldsen, R., Loeng, H., Mork, K. A., Orvik, K. A. and Ozhigin, V.: Volume and heat transports to the Arctic Ocean via the Norwegian and Barents seas, in Arctic Subarctic Ocean Fluxes: Defining the Role of the Northern Seas in Climate, , Edited by R. Dickson, J. Meincke, and P. Rhines(Springer, New York), 45-64, 2008.

Skagseth, Ø., Drinkwater, K. F. and Terrile, E.: Wind- and buoyancy-induced transport of the Norwegian Coastal Current in the Barents Sea, J. Geophys. Res., 116(C8), doi:10.1029/2011JC006996, 2011.

Smedsrud, L. H., Ingvaldsen, R., Nilsen, J. E. $\varnothing$. and Skagseth, $\varnothing .:$ Heat in the Barents Sea: transport, storage, and surface fluxes, Ocean Sci., 6(1), 219-234, doi:10.5194/os-6-219-2010, 2010.

de Steur, L., Hansen, E., Mauritzen, C., Beszczynska-M?ller, A. and Fahrbach, E.: Impact of recirculation on the East Greenland Current in Fram Strait: Results from moored current meter measurements between 1997 and 2009, Deep Sea Res. Part Oceanogr. Res. Pap., 92, 26-40, doi:10.1016/j.dsr.2014.05.018, 2014.

Storto, A.: Variational quality control of hydrographic profile data with non-Gaussian errors for global ocean variational data assimilation systems, Ocean Model., 104, 226-241, doi:10.1016/j.ocemod.2016.06.011, 2016.

Storto, A. and Masina, S.: C-GLORSv5: an improved multipurpose global ocean eddy-permitting physical reanalysis, Earth Syst. Sci. Data, 8(2), 679-696, doi:10.5194/essd-8-679-2016, 2016 a.

Storto, A. and Masina, S.: The CMCC Eddy-permitting Global Ocean Physical Reanalysis (C-GLORS v5, 1980-2014), , doi:10.1594/PANGAEA.857995, 2016b.

Storto, A., Masina, S. and Dobricic, S.: Estimation and Impact of Nonuniform Horizontal Correlation Length Scales for Global Ocean Physical Analyses, J. Atmospheric Ocean. Technol., 31(10), 2330-2349, doi:10.1175/JTECH-D-14-00042.1, 2014. 
Storto, A., Masina, S., Balmaseda, M., Guinehut, S., Xue, Y., Szekely, T., Fukumori, I., Forget, G., Chang, Y.-S., Good, S. A., Köhl, A., Vernieres, G., Ferry, N., Peterson, K. A., Behringer, D., Ishii, M., Masuda, S., Fujii, Y., Toyoda, T., Yin, Y., Valdivieso, M., Barnier, B., Boyer, T., Lee, T., Gourrion, J., Wang, O., Heimback, P., Rosati, A., Kovach, R., Hernandez, F., Martin, M. J., Kamachi, M., Kuragano, T., Mogensen, K., Alves, O., Haines, K. and Wang, X.: Steric sea level variability (1993-2010) in an ensemble of ocean reanalyses and objective analyses, Clim. Dyn., 1-21, doi:10.1007/s00382-015-2554-9, 2015.

Storto, A., Masina, S. and Navarra, A.: Evaluation of the CMCC eddy-permitting global ocean physical reanalysis system (CGLORS, 1982-2012) and its assimilation components: Evaluation of C-GLORS Global Ocean Reanalysis, Q. J. R. Meteorol. Soc., 142(695), 738-758, doi:10.1002/qj.2673, 2016.

Stroeve, J. C., Kattsov, V., Barrett, A., Serreze, M., Pavlova, T., Holland, M. and Meier, W. N.: Trends in Arctic sea ice extent from CMIP5, CMIP3 and observations, Geophys. Res. Lett., 39(16), doi:10.1029/2012GL052676, 2012.

Tsubouchi, T., Bacon, S., Naveira Garabato, A. C., Aksenov, Y., Laxon, S. W., Fahrbach, E., Beszczynska-Möller, A., Hansen, E., Lee, C. M. and Ingvaldsen, R. B.: The Arctic Ocean in summer: A quasi-synoptic inverse estimate of boundary fluxes and water mass transformation, J. Geophys. Res. Oceans, 117(C1), doi:10.1029/2011JC007174, 2012.

Tsubouchi, T., Bacon, S., Naveira Garabato, A. C., Aksenov, Y., Schauer, U., Beszczynska-Möller, A., Hansen, E. H., de Steur, L., Lee, C., Curry, B. and Ingvaldsen, R.: Pan-Arctic Oceanic volume, heat and freshwater transport time series during 2005 to 2006, link to model results in NetCDF Format., PANGAEA - Data Publ. Earth Environ. Sci., doi:10.1594/PANGAEA.870607, 2017.

Tsubouchi, T., Bacon, S., Aksenov, Y., Naveira Garabato, A. C., Beszczynska-Möller, A., Hansen, E., de Steur, L., Curry, B. and Lee, C. M.: The Arctic Ocean Seasonal Cycles of Heat and Freshwater Fluxes: Observation-Based Inverse Estimates. J. Phys. Oceanogr., 48, 2029-2055, https://doi.org/10.1175/JPO-D-17-0239.1, 2018.

Uotila, P., Goosse, H., Haines, K., Chevallier, M., Barthélemy, A., Bricaud, C., Carton, J., Fučkar, N., Garric, G., Iovino, D., Kauker, F., Korhonen, M., Lien, V. S., Marnela, M., Massonnet, F., Mignac, D., Peterson, K. A., Sadikni, R., Shi, L., Tietsche, S., Toyoda, T., Xie, J. and Zhang, Z.: An assessment of ten ocean reanalyses in the polar regions, Clim. Dyn., doi:10.1007/s00382-018-4242-z, 2018.

Valdivieso, M., Haines, K., Zuo, H. and Lea, D.: Freshwater and heat transports from global ocean synthesis, J. Geophys. Res. Oceans, 119(1), 394-409, doi:10.1002/2013JC009357, 2014.

Wekerle, C., Wang, Q., Danilov, S., Schourup-Kristensen, V., von Appen, W.-J. and Jung, T.: Atlantic Water in the Nordic Seas: Locally eddy-permitting ocean simulation in a global setup: ATLANTIC WATER IN THE NORDIC SEAS, J. Geophys. Res. Oceans, 122(2), 914-940, doi:10.1002/2016JC012121, 2017.

Woodgate, R., Stafford, K. and Prahl, F.: A Synthesis of Year-Round Interdisciplinary Mooring Measurements in the Bering Strait (1990-2014) and the RUSALCA Years (2004-2011), Oceanography, 28(3), 46-67, doi:10.5670/oceanog.2015.57, 2015.

Woodgate, R. A.: Increases in the Pacific inflow to the Arctic from 1990 to 2015, and insights into seasonal trends and driving mechanisms from year-round Bering Strait mooring data, Prog. Oceanogr., 160, 124-154, doi:10.1016/j.pocean.2017.12.007, 2018.

Woodgate, R. A., Aagaard, K. and Weingartner, T. J.: A year in the physical oceanography of the Chukchi Sea: Moored measurements from autumn 1990-1991, Deep Sea Res. Part II Top. Stud. Oceanogr., 52(24-26), 3116-3149, doi:10.1016/j.dsr2.2005.10.016, 2005a. 
Woodgate, R. A., Aagaard, K. and Weingartner, T. J.: Monthly temperature, salinity, and transport variability of the Bering Strait through flow, Geophys. Res. Lett., 32(4), doi:10.1029/2004GL021880, 2005b.

Woodgate, R. A., Weingartner, T. and Lindsay, R.: The 2007 Bering Strait oceanic heat flux and anomalous Arctic sea-ice retreat, Geophys. Res. Lett., 37(1), doi:10.1029/2009GL041621, 2010.

Woodgate, R. A., Weingartner, T. J. and Lindsay, R.: Observed increases in Bering Strait oceanic fluxes from the Pacific to the Arctic from 2001 to 2011 and their impacts on the Arctic Ocean water column, Geophys. Res. Lett., 39(24), doi:10.1029/2012GL054092, 2012.

Yang, C., Masina, S., Bellucci, A. and Storto, A.: The Rapid Warming of the North Atlantic Ocean in the Mid-1990s in an Eddy-Permitting Ocean Reanalysis (1982-2013), J. Clim., 29(15), 5417-5430, doi:10.1175/JCLI-D-15-0438.1, 2016.

Zhang, J. and Rothrock, D. A.: Modeling Global Sea Ice with a Thickness and Enthalpy Distribution Model in Generalized Curvilinear Coordinates, Mon. Weather Rev., 131(5), 845-861, doi:10.1175/15200493(2003)131<0845:MGSIWA>2.0.CO;2, 2003.

Zuo, H., Mugford, R. I., Haines, K. and Smith, G. C.: Assimilation impacts on Arctic Ocean circulation, heat and freshwater budgets, Ocean Model., 40(2), 147-163, doi:10.1016/j.ocemod.2011.08.008, 2011. 


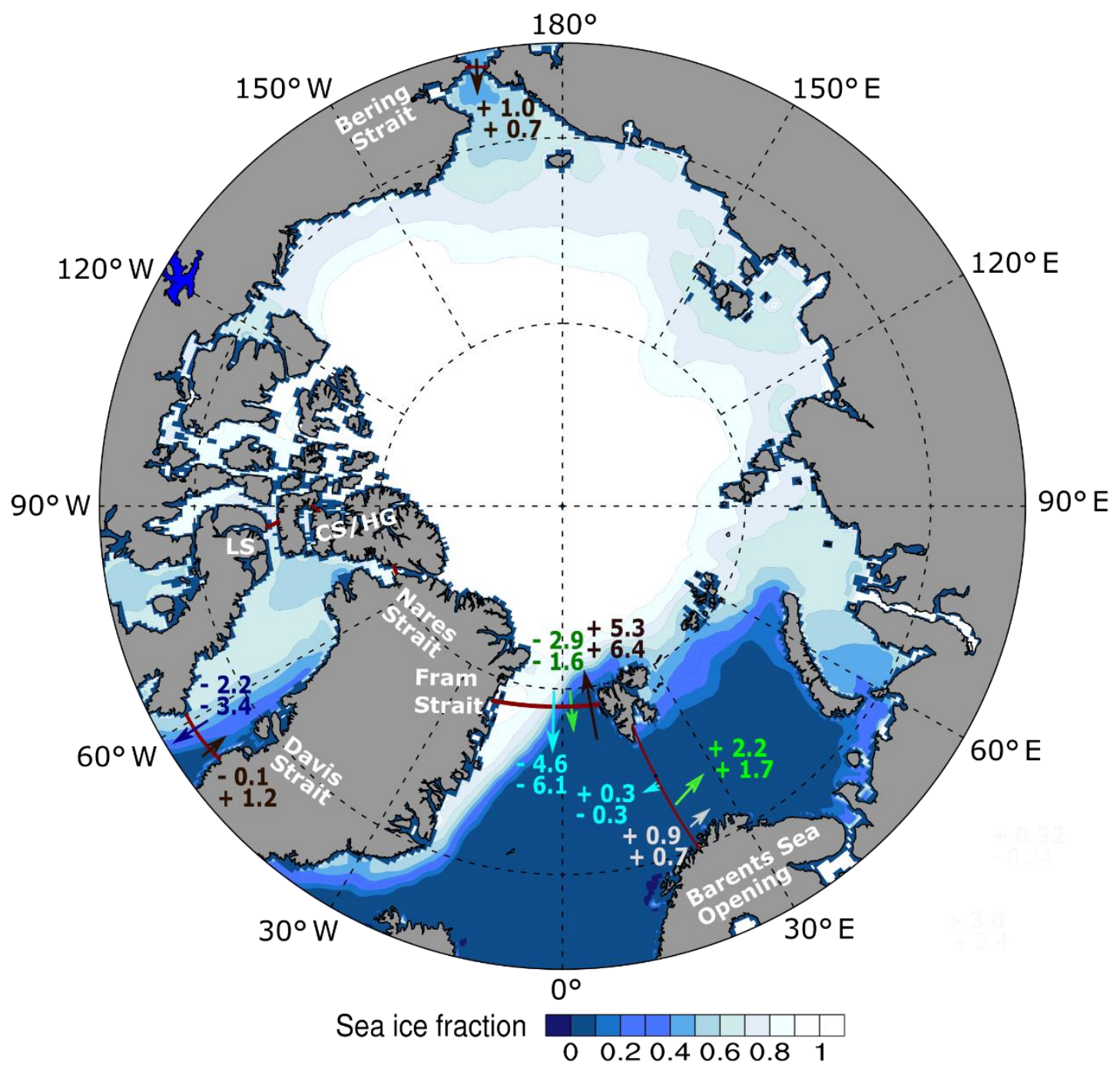

Figure 1: Overview map of the Arctic Ocean, showing the four main gateways (Davis Strait, Fram Strait, the Barents Sea Opening and Bering Strait). The volume transports (in Sv) averaged over the study period 09/2005 - 08/2006 of the main currents through these straits are given for the reanalysis (C-GLROSv7, top value) and below that the observation-based estimate. The location of the Canadian Straits (Nares Strait, Lancaster Sound (LS) and Hell Gate/Cardigan Strait $(\mathrm{HG} / \mathrm{CS})$ ) are marked. The sea ice fraction (obtained from PIOMAS for our study period from September 2005 to August 2006) is shown in shades of blue (0) to white (1). 

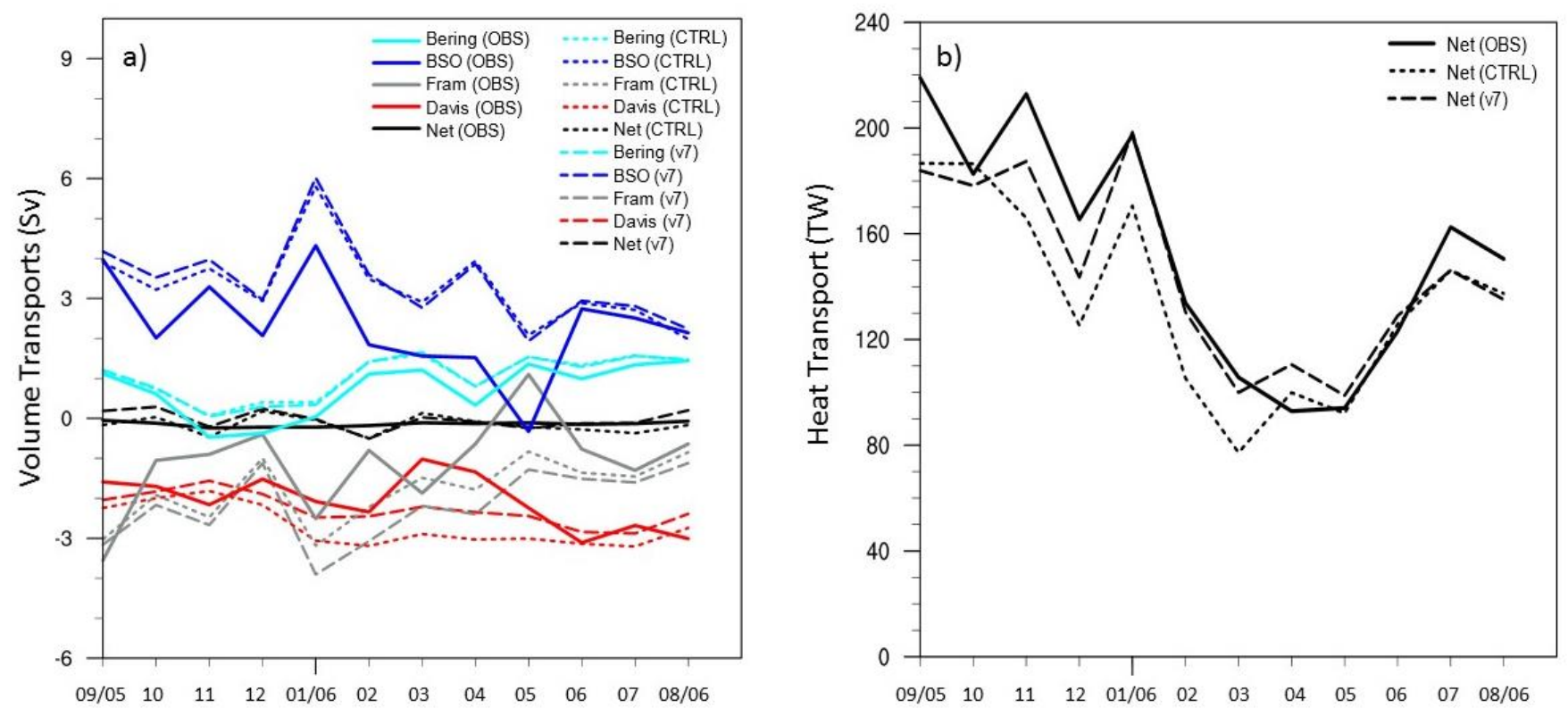

Figure 2: Time series of (a) volume transports and (b) net heat transport from the observation-based dataset ("OBS”, solid lines) and from the reanalysis C-GLORSv7 ("v7", dashed, control experiment "CTRL", dotted). The study period averages for the observation-based data and the reanalysis are given in Tab. 1. 
a) Velocity $(\mathrm{m} / \mathrm{s})$
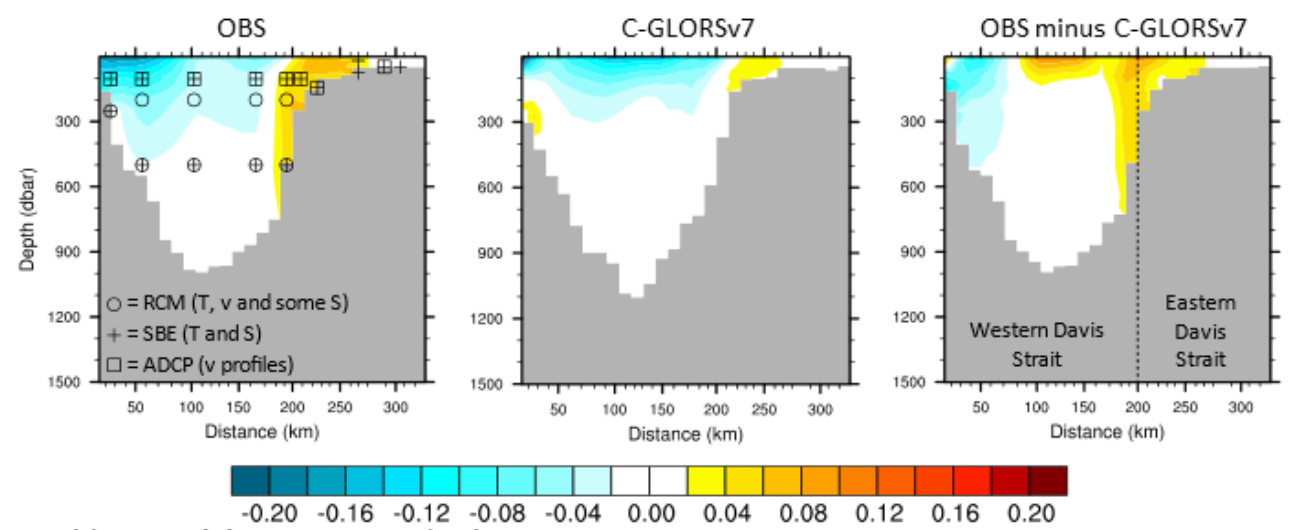

b) Potential temperature $\left({ }^{\circ} \mathrm{C}\right)$
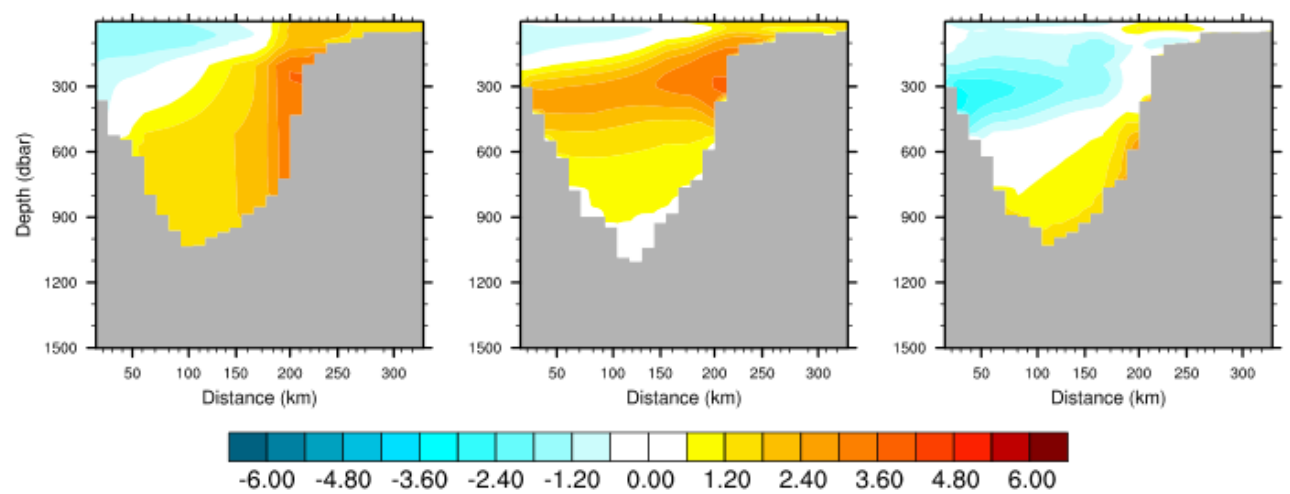

Figure 3a: (a) Velocity in $\mathrm{m} / \mathrm{s}$ and (b) potential temperature in ${ }^{\circ} \mathrm{C}$ cross-section plots for Davis Strait obtained from the observation-based dataset (OBS), C-GLORS version 7 and the difference between the two. The plots show averages of the fields over the one-year study period. The distance (x-axis) is the great circle distance to a point on the coast of Baffin Island $\left(66.6^{\circ} \mathrm{N}\right.$ and $\left.61.3^{\circ} \mathrm{W}\right)$. Positive velocities signify Arctic inflow and are directed into the paper. The symbols in the observation-based cross-section show the locations of moored instruments in the strait. A combination of two symbols signifies locations of both instrument types. 
a) Velocity $(\mathrm{m} / \mathrm{s})$

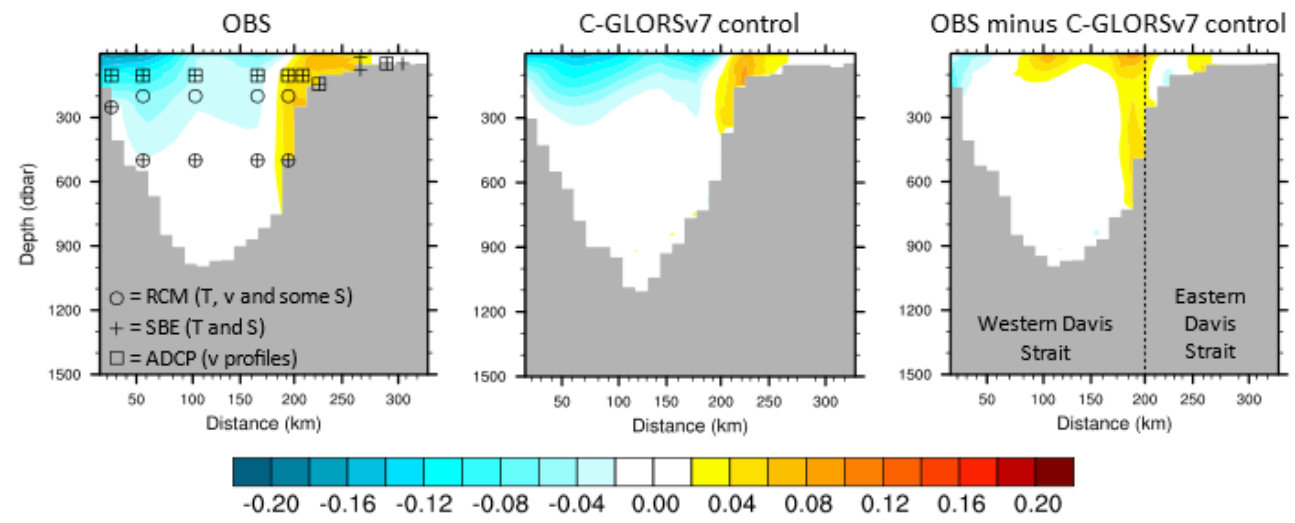

b) Potential temperature $\left({ }^{\circ} \mathrm{C}\right)$

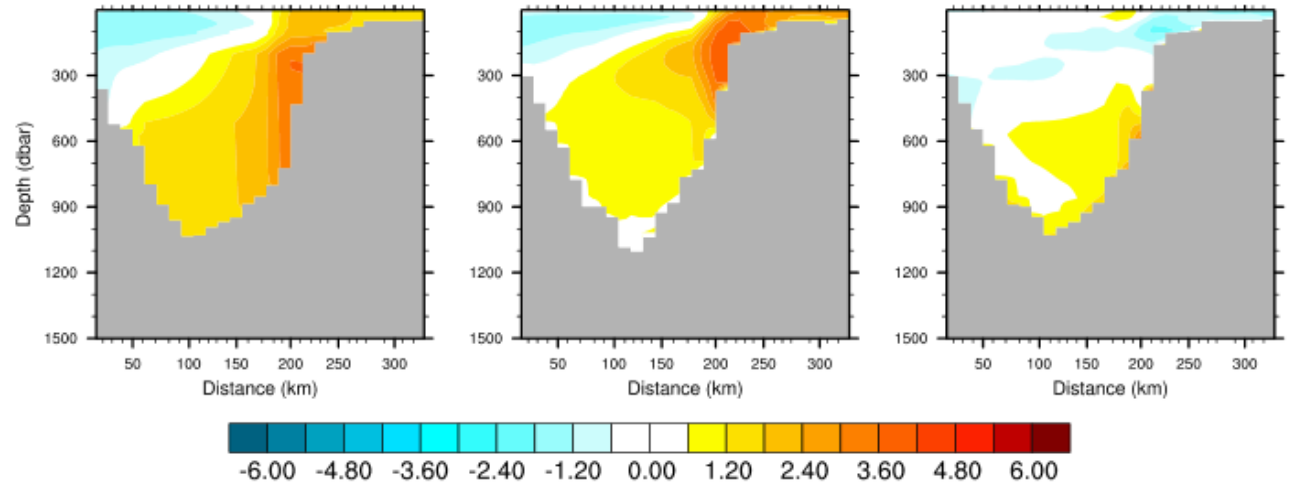

Figure 3b: Same as Figure 3a, but for the control experiment (C-GLORSv7 control). 
a) Velocity $(\mathrm{m} / \mathrm{s})$
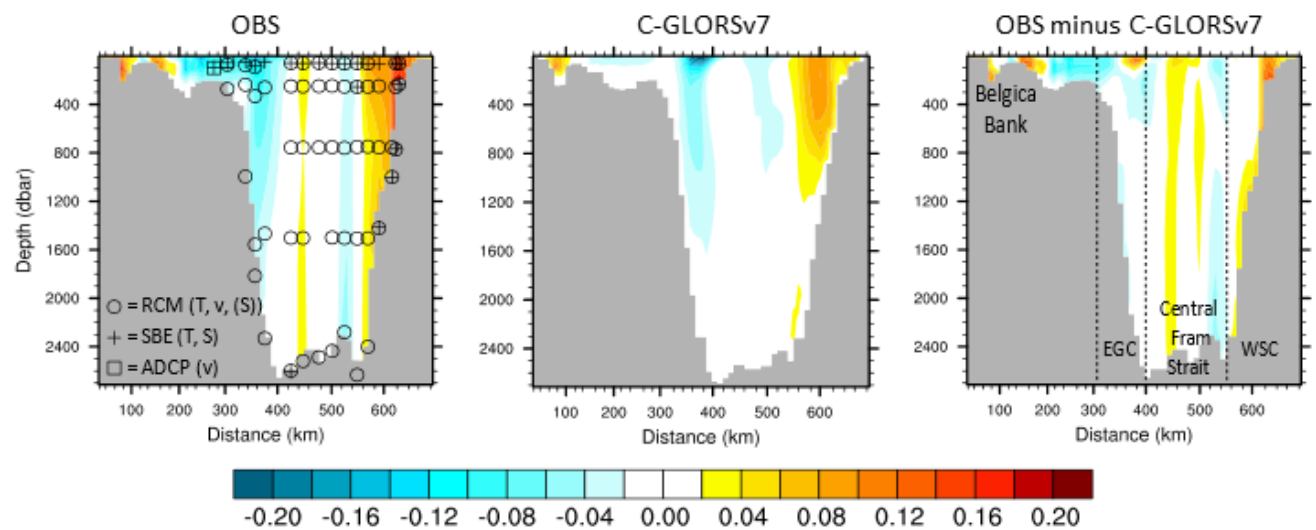

b) Potential temperature $\left({ }^{\circ} \mathrm{C}\right)$
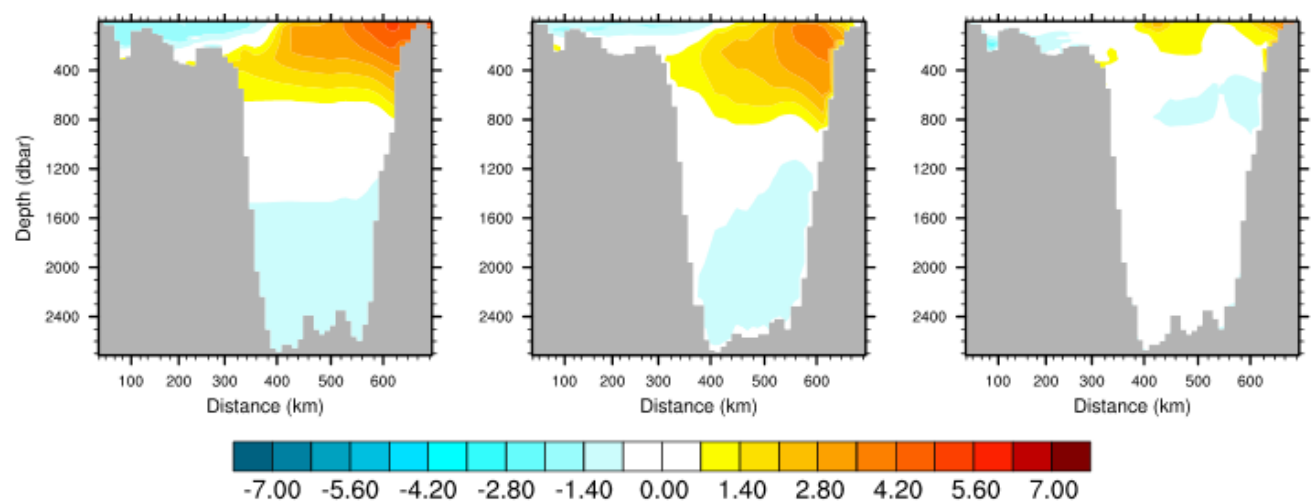

Figure 4: Fram Strait cross-sections for (a) velocity and (b) potential temperature averaged over the study period for the observation-based dataset (OBS), C-GLORS version 7 and the difference between the two. Distances are calculated with respect to $78.8^{\circ} \mathrm{N}$ and $20.6^{\circ} \mathrm{W}$. 
a) Velocity $(\mathrm{m} / \mathrm{s})$
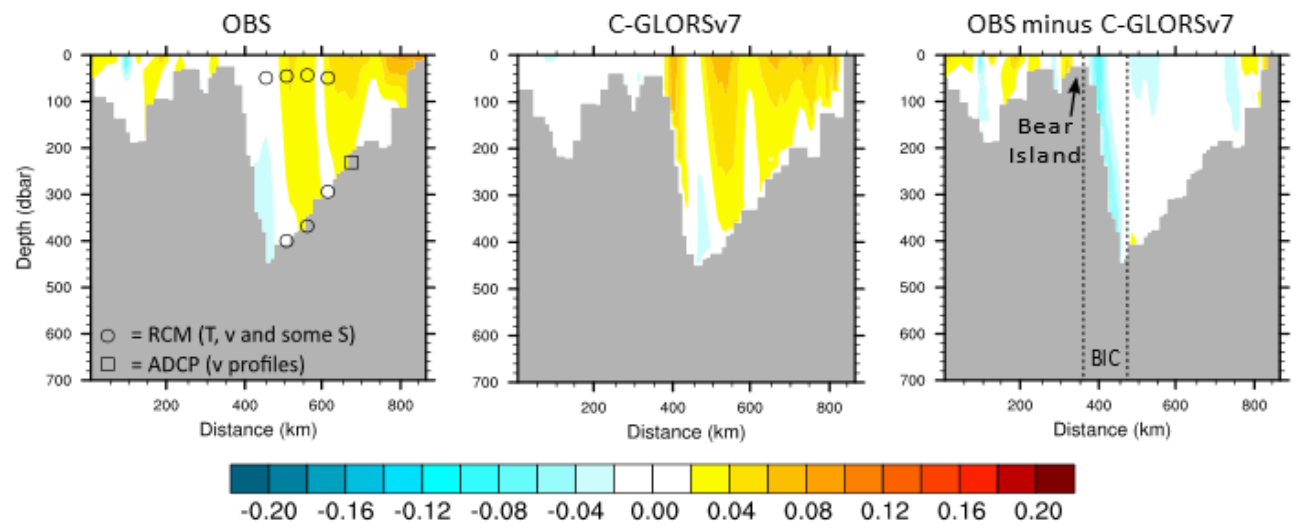

b) Potential temperature $\left({ }^{\circ} \mathrm{C}\right)$

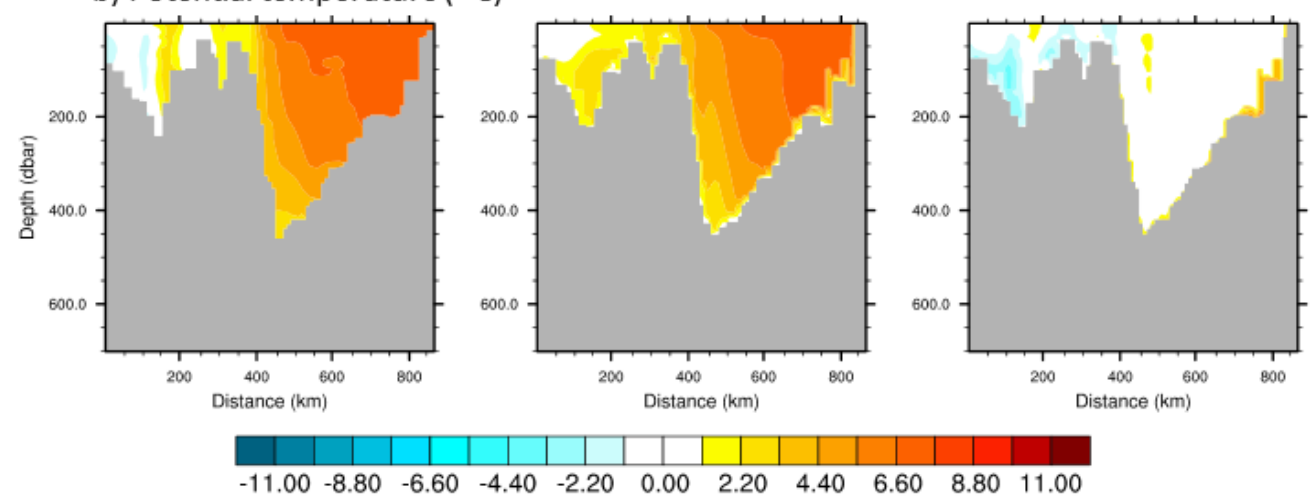

Figure 5: Barents Sea Opening cross-sections for (a) velocity and (b) potential temperature averaged over the study period for the observation-based dataset (OBS), C-GLORS version 7 and the difference between the two. Distances are calculated with respect to $77.5^{\circ} \mathrm{N}$ and $18.1^{\circ} \mathrm{E}$. 
a) Velocity $(\mathrm{m} / \mathrm{s})$
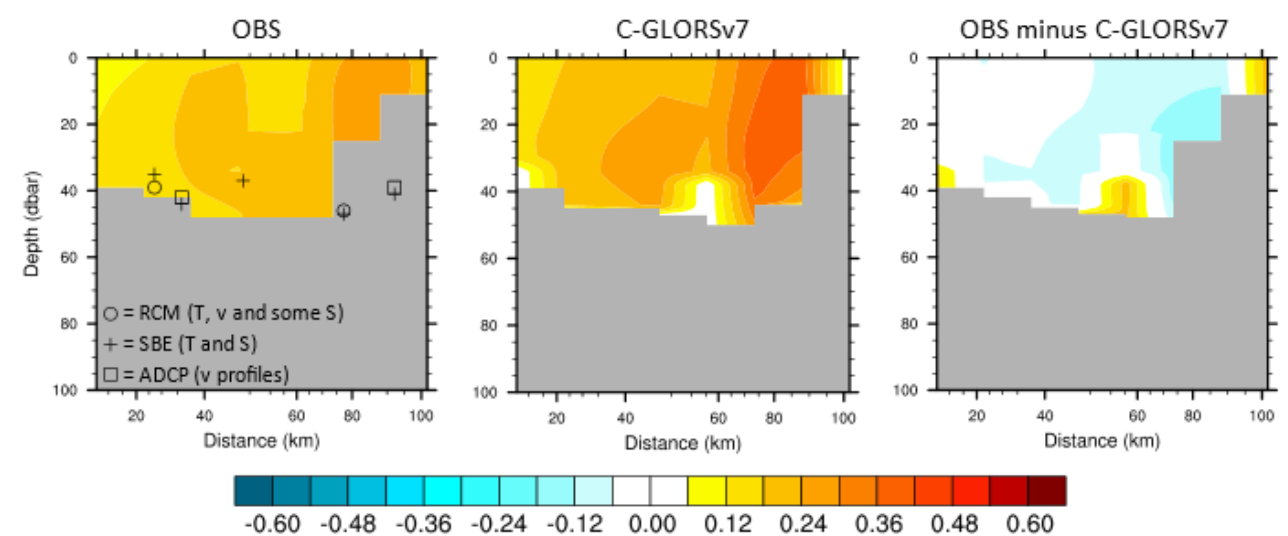

b) Potential temperature $\left({ }^{\circ} \mathrm{C}\right)$
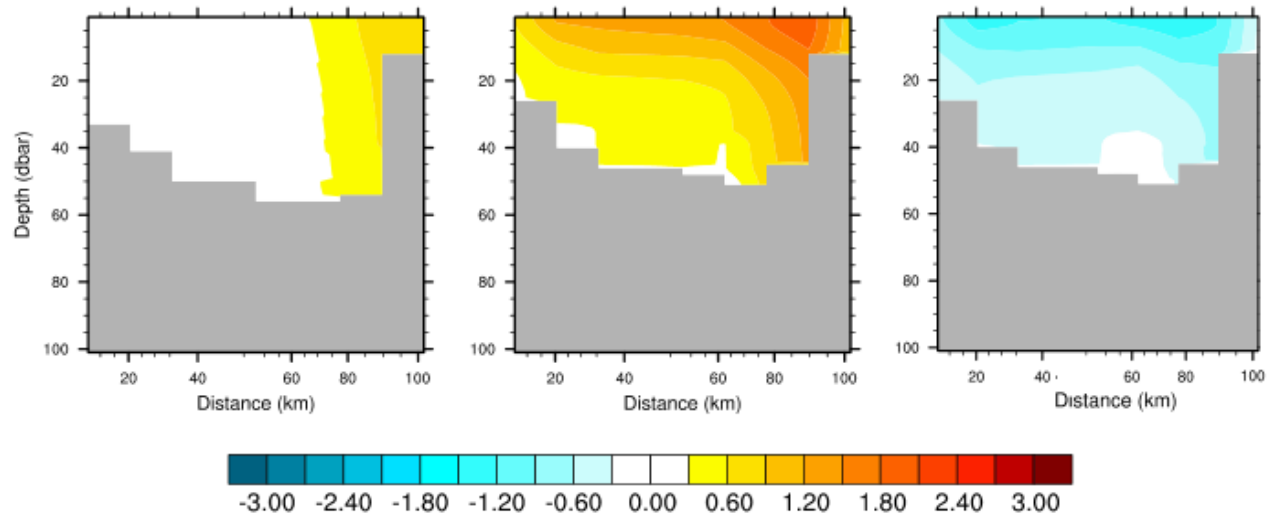

Figure 6: Bering Strait cross-sections for (a) velocity and (b) potential temperature averaged over the study period. Distances are calculated with respect to $66.0^{\circ} \mathrm{N}$ and $170.2^{\circ} \mathrm{W}$. The different shape of the observation-based velocity cross-sections compared to temperature cross-sections is due to temperatures being given in slightly different locations and having a different spatial coverage than the velocities. Interpolation of temperatures to the velocity grid for calculating temperature transports, and horizontal averaging of the temperature and velocity fields to meet the horizontal resolution of the reanalysis grid lead to different spatial coverage in the plots. The same happens in the other straits, but it is less obvious there due to the larger cross-section areas. 


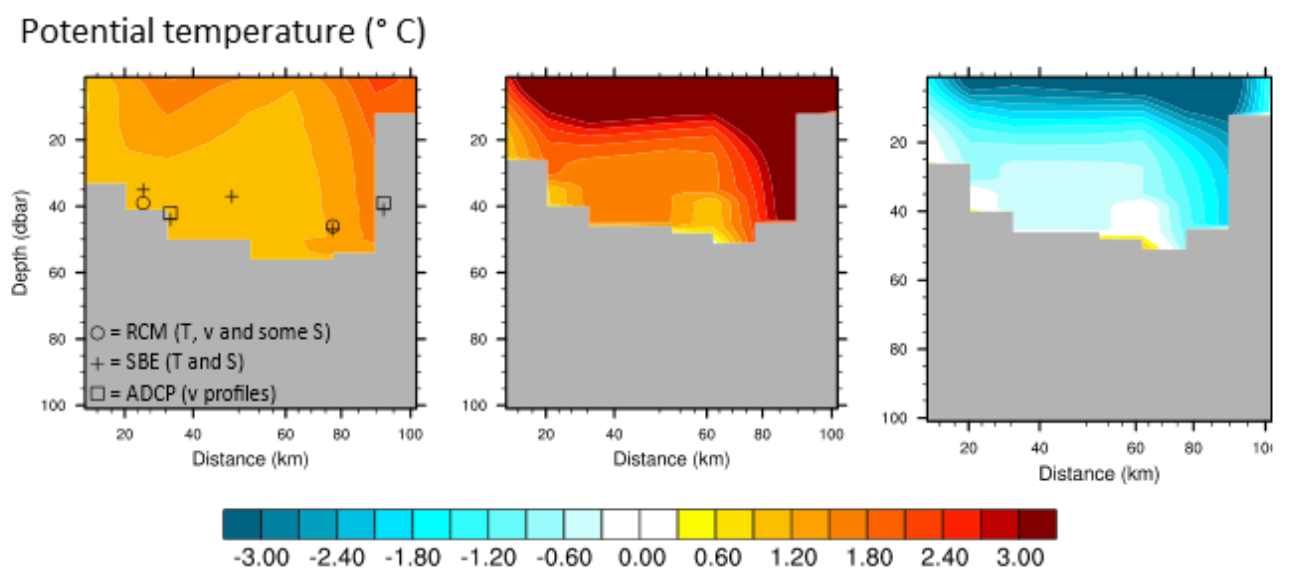

Figure 7: Bering Strait potential temperature distribution during summer 2006 (averaged over June, July and August). 


\begin{tabular}{|c|c|c|c|c|c|c|c|c|c|c|}
\hline & \multicolumn{5}{|c|}{ Volume Transport (Sv) } & \multicolumn{5}{|c|}{ Heat Transport (TW) } \\
\hline & OBS & C-GLORS & $\mathbf{r}$ & RMSD & $\Delta$ & OBS & C-GLORS & $\mathbf{r}$ & RMSD & $\Delta$ \\
\hline Net & $-0.15 \pm 0.06$ & $\begin{array}{l}-0.03 \pm 0.23 \\
-0.16 \pm 0.22\end{array}$ & $\begin{array}{l}0.33 \\
0.12\end{array}$ & $\begin{array}{l}0.24 \\
0.21\end{array}$ & $\begin{array}{r}-0.12 \\
0.01\end{array}$ & $153 \pm 44$ & $\begin{array}{l}145 \pm 35 \\
135 \pm 37\end{array}$ & $\begin{array}{l}0.96 \\
0.91\end{array}$ & $\begin{array}{l}17 \\
25\end{array}$ & $\begin{array}{c}8 \\
18\end{array}$ \\
\hline Davis & $-2.1 \pm 0.7$ & $\begin{array}{l}-2.3 \pm 0.4 \\
-2.7 \pm 0.5\end{array}$ & $\begin{array}{l}0.56 \\
0.34\end{array}$ & $\begin{array}{l}0.57 \\
0.91\end{array}$ & $\begin{array}{l}0.2 \\
0.6\end{array}$ & & & & & \\
\hline Fram & $-1.1 \pm 1.2$ & $\begin{array}{l}-2.2 \pm 0.9 \\
-1.8 \pm 0.8\end{array}$ & $\begin{array}{l}0.68 \\
0.76\end{array}$ & $\begin{array}{l}1.35 \\
1.00\end{array}$ & $\begin{array}{l}1.1 \\
0.7\end{array}$ & & & & & \\
\hline BSO & $2.3 \pm 1.2$ & $\begin{array}{l}3.4 \pm 1.1 \\
3.3 \pm 1.0\end{array}$ & $\begin{array}{l}0.76 \\
0.69\end{array}$ & $\begin{array}{l}1.35 \\
1.32\end{array}$ & $\begin{array}{l}-1.1 \\
-1.0\end{array}$ & & & & & \\
\hline Bering & $0.7 \pm 0.7$ & $\begin{array}{l}1.0 \pm 0.6 \\
1.0 \pm 0.5\end{array}$ & $\begin{array}{l}0.97 \\
0.97\end{array}$ & $\begin{array}{l}0.36 \\
0.38\end{array}$ & $\begin{array}{l}-0.3 \\
-0.3\end{array}$ & & & & & \\
\hline
\end{tabular}

Table 1: This Table is a comparison of the different reanalysis experiments (C-GLORSv7 in black, the control run in blue) with the observation-based dataset (OBS). The values are the annual averages of the integrated volume transports (in Sv) through each strait and the net volume and heat transport (in TW). Each value is given with monthly standard deviations calculated for the one-year study period. Cross correlation $r$ between the reanalaysis and the observationbased time series, root mean square deviation and average difference ( $\Delta=$ OBS minus C-GLORSv7) are given as well. 